\title{
WestVirginiaUniversity
}

THE RESEARCH REPOSITORY @ WVU

Graduate Theses, Dissertations, and Problem Reports

2014

\section{Military Versus Civilian Murder-Suicide Psychological Profiles}

\author{
Christina Patton \\ West Virginia University
}

Follow this and additional works at: https://researchrepository.wvu.edu/etd

\section{Recommended Citation}

Patton, Christina, "Military Versus Civilian Murder-Suicide Psychological Profiles" (2014). Graduate Theses, Dissertations, and Problem Reports. 130.

https://researchrepository.wvu.edu/etd/130

This Thesis is protected by copyright and/or related rights. It has been brought to you by the The Research Repository @ WVU with permission from the rights-holder(s). You are free to use this Thesis in any way that is permitted by the copyright and related rights legislation that applies to your use. For other uses you must obtain permission from the rights-holder(s) directly, unless additional rights are indicated by a Creative Commons license in the record and/ or on the work itself. This Thesis has been accepted for inclusion in WVU Graduate Theses, Dissertations, and Problem Reports collection by an authorized administrator of The Research Repository @ WVU. For more information, please contact researchrepository@mail.wvu.edu. 


\title{
Military Versus Civilian Murder-Suicide Psychological Profiles
}

\author{
Christina Patton \\ MASTER'S THESIS \\ Submitted to the Eberly College of Arts and Sciences \\ At West Virginia University \\ Master of Science \\ in \\ Psychology \\ William Fremouw, Ph.D., Chair \\ Amy Fiske, Ph.D. \\ Karen G. Anderson, Ph.D. \\ Department of Psychology \\ Morgantown, West Virginia \\ 2014
}

In partial fulfillment of the requirement for the degree of

Keywords: military violence, military crime, murder-suicide, suicide, intimate partner violence Copyright 2014 (Christina Patton) 


\section{ABSTRACT \\ Military Versus Civilian Murder-Suicide Psychological Profiles}

\section{Christina Patton}

Previous studies have implicated dramatic differences between military members and civilians with regard to violent behavior, including suicide, domestic violence, and harm to others, but none have examined military murder-suicide. This study compared military and civilian murder-suicide perpetrators on a number of demographic, psychological, and contextual factors. Military murder-suicide perpetrators were more likely to be older, suffer physical health disparities, be currently or formerly married, and less likely to abuse substances. They were also more likely than civilians to complete a murder-suicide due to a motive of depression, rather than one of jealousy or anger related to relationship dissolution. Logistic regression revealed that membership to the military, rather than the civilian, perpetrator group was predicted by age, reflecting the significance of a more than 15-year difference in mean age between the two groups and suggesting that many of the differences observed between the groups could be at least partially attributable to age effects. Findings from this study point to the need to tailor suicide risk assessments to include questions specific to murder-suicide and violence to others, and to add additional questions focusing on elucidating the perpetrator's attitudes toward suicide and murder-suicide. Other findings highlight the importance of assessing suicide and violence risk in older adult military populations, as they complete the majority of military murder-suicides, and of revamping existing clinical interventions to address demographical differences of military perpetrators. 


\section{Acknowledgements}

I would like to thank Bill Fremouw, Amy Fiske, and Karen Anderson for serving as members of my thesis committee and for their valuable comments in preparing this manuscript. I am particularly thankful to Bill for serving as my committee chair and advisor over the past two years. 
Table of Contents

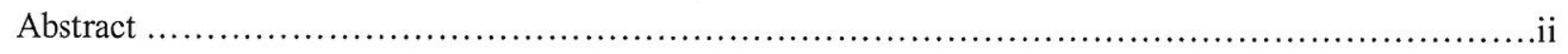

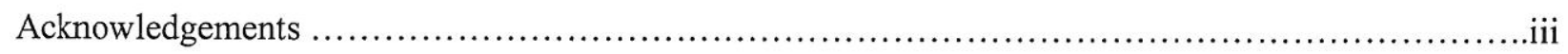

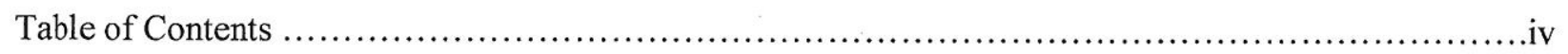

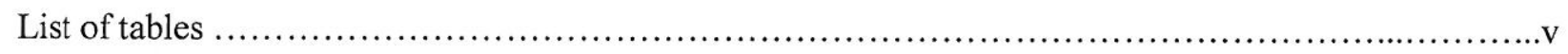

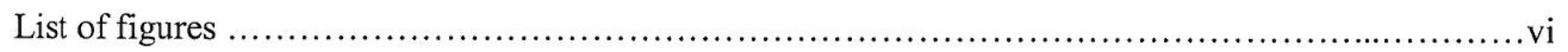

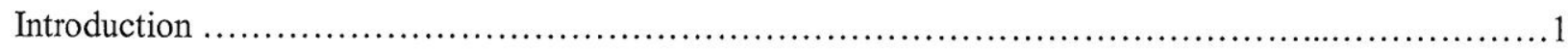

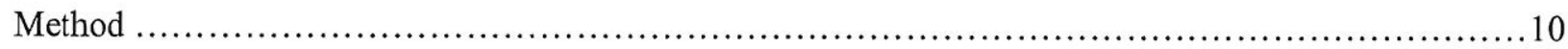

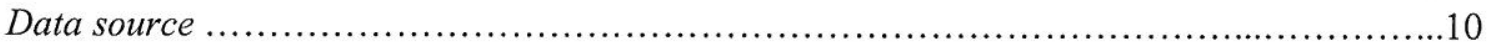

Participants .................................................................... 11

Analysis ........................................................................ 13

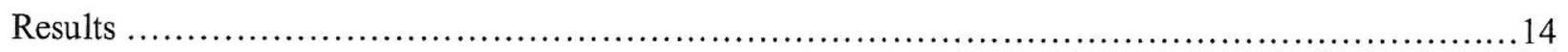

Chi-squared analyses ..............................................................

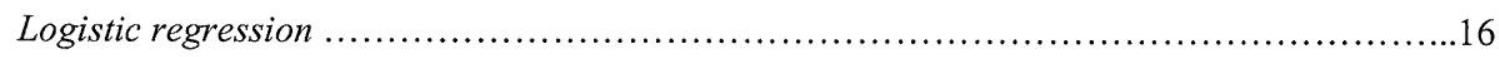

Post-hoc analyses ..............................................................

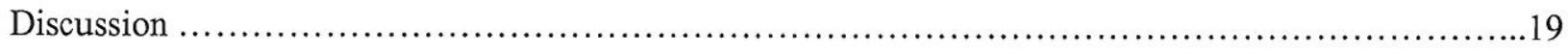

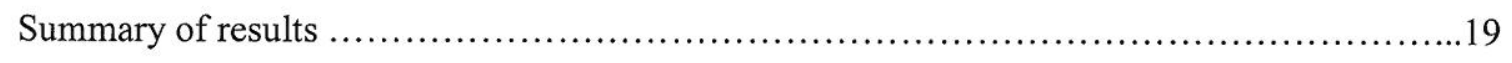

Age effects and protective factors of military service ..................................20

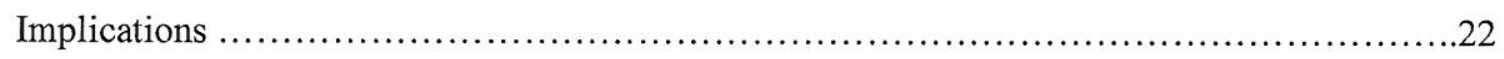

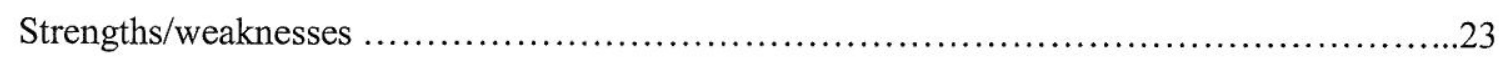

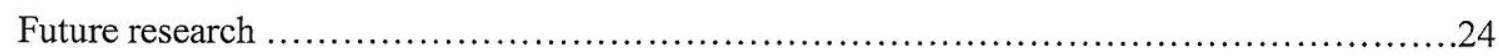

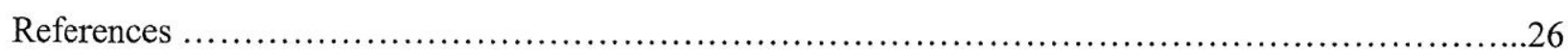

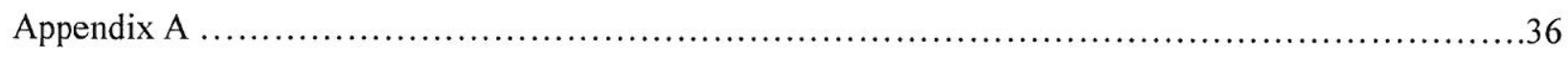

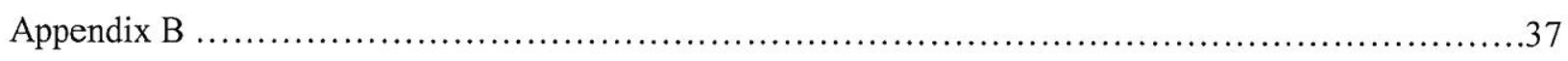

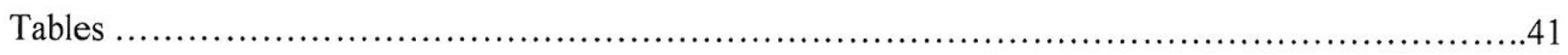

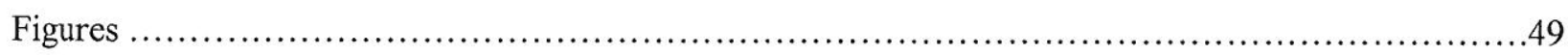




\section{List of tables}

Table 1. Comparison of demographic characteristics of military versus civilian murder-suicide perpetrators. Variables in bold were identified by cross-tabulation to be significantly different from one another. Mean age of murder-suicide perpetrators was compared using an independent t-test.

Table 2. Victim relationship to perpetrator and primary motive. Variables in bold were identified by cross-tabulation to be significantly different from one another.

Table 3. Behavioral health characteristics of military versus civilian murder-suicide perpetrators. Variables in bold were identified by cross-tabulation to be significantly different from one another.

Table 4. Event-contextual characteristics of military versus civilian murder-suicides. Variables in bold were identified by cross-tabulation to be significantly different from one another. More than one type of stressor may have been endorsed in each case.

Table 5. Logistic regression for military versus civilian perpetrators with age included as a predictor. $0=$ civilians, $1=$ military. Cox and Snell R2 $=.214$, Nagelkerke $\mathrm{R} 2=.285$. Variables in bold identified as significant. Jealousy/anger related to relationship dissolution was used as the comparison group for the step containing motives. The odds ratio is used to describe the relative odds of membership to the civilian perpetrator group, given exposure to the variable of interest. Values of greater than one indicate that members of the civilian perpetrator group are more likely than military perpetrators to be exposed to that variable. Non-significant values for the Hosmer and Lemeshow test are desired and suggests the model fits the data well.

Table 6. Logistic regression for military versus civilian perpetrators including only secondary predictors (age excluded). $0=$ civilians, $1=$ military. Cox and Snell R2 $=.214$, Nagelkerke $\mathrm{R} 2=.285$. Variables in bold identified as significant. The odds ratio is used to describe the relative odds of membership to the civilian perpetrator group, given exposure to the variable of interest. Values of greater than one indicate that members of the civilian perpetrator group are more likely than military perpetrators to be exposed to that variable. Non-significant values for the Hosmer and Lemeshow test is desired and suggests the model fits the data well.

Table 7. Correlations between demographic factors, motives, behavioral health variables, and eventcontextual factors identified as significant in univariate analyses. ${ }^{* *}$ Correlation is significant at the .01 level. *Correlation is significant at the .05 level.

Table 8. Comparison of mean age of murder-suicide and suicide-only perpetrators. Variables in bold were identified as significantly different from one another in an independent $t$-test, $\mathrm{p}<.001$. 


\section{List of figures}

Figure 1. Percentage of all cases of murder-suicide with jealousy/anger motive calculated for each age aggregate.

Figure 2. Percentage of all murder-suicides with the depression/psychache motive calculated for each age aggregate. 


\section{Military Versus Civilian Murder-Suicide Psychological Profiles}

Murder-suicide is described as "a two-stage sequential act in which a person kills one or more individuals and then commits suicide shortly thereafter" (Logan et al., 2008). Although no standard time interval definition exists, it is widely accepted that the suicide should take place within 24 hours of the murder(s) to be considered a murder-suicide (Nock \& Marzuk, 1999). These deaths receive much publicity and attention in the media. Headlines such as "NFL linebacker kills his baby's mother, then himself as coaches look on" (Botelho, 2012) and "Killer commits suicide after massacre at school" (Associated Press, 2012) inundate the national news on a regular basis, but estimates of prevalence are much lower than the media coverage would suggest. Generally, rates of murder-suicide range from 0.5-0.11 of every 100,000 persons internationally (Carcach \& Grabosky, 1998; Flynn et al., 2009; Moskowitz, Simpson, McKenna, Skipworth \& Barry-Walsh, 2006) to more than double that, $0.27-0.38$ of every 100,000 persons in the U.S. (Hannah, Turf \& Fiero, 1998; Walsh \& Hemenway, 2005) annually. To put this in perspective, Marzuk, Tardiff, and Hirsch (1992) illustrated that the annual murder-suicide mortality rates in the United States (using 1,000 to 1,500 a year) is similar to those of infectious diseases like tuberculosis $(1,467$ deaths), viral hepatitis (1,290 deaths), influenza (1,943 deaths), and meningitis (1,156 deaths).

One specific subtype of murder-suicide (male intimate partner perpetrator, female partner victim) comprises over half of all incidents (Liem, 2010). In fact, previous research designed to compare murdersuicide to other homicides confirms the overwhelming domestic influence of murder-suicide, meaning that most incidents happen in or near the home and involve romantic partners or family members (West, 1965). This research finding has been echoed by more recent studies, indicating that domestic violence may precede a majority of incidents of murder-suicide (Bossarte, Simon, \& Baker, 2006; Malphurs \& Cohen, 2002; Yip, Wong, Cheung, Chan, \& Beh, 2009). Logan et al. (2008) found that among incidents with male perpetrators, the vast majority of victims were female intimate partners, and that if additional victims were noted, these were most often children of the victim also present in the home. Compared to men that had only completed suicide, the men that completed murder-suicide were significantly more likely to have a 
history of intimate-partner conflict, and as many as $40 \%$ of these perpetrators were believed to have sought retaliation in response to a divorce request or break-up. These findings may suggest the appropriateness of targeted intervention strategies for victims and perpetrators of intimate partner violence, and increased awareness of murder-suicide risk following situational stressors (Bossarte et al., 2006).

\section{Typologies of Murder-Suicide}

Several researchers have attempted to classify types of murder-suicides based on offender characteristics. Murder-suicide was first studied by sociologist Ruth Cavan (1928), who examined 39 murder-suicides that occurred in the Chicago area in 1923 and concluded that "murder-suicide, whether planned or impulsive, is the result of one emotional outburst with no intervening period of remorse or fear between the two acts" (Harper \& Voigt, 2007, p. 299). In a study of 148 murder-suicide cases occurring in England and Wales from 1954-1961, West (1965) concluded that most murder-suicides involved family members, and the act was a natural extension of the perpetrator's own desire for death. Berman (1979) established a method of categorizing offenders, and hypothesized that intimate partners who later completed murder-suicide could be divided into two types based on the perspective of "ego fusion": the "eroticaggressive" type, or when the relationship roles of offender and victim appear mutually interchangeable, and the "dependent-protective" type, or when the homicide victim is viewed as dependent on the caretaking functions of the perpetrator.

Marzuk et al. (1992; MTH typology) were the first to develop a comprehensive classification system that grouped occurrences of murder-suicide by victim-perpetrator relationship and common precipitants or motives (Nock \& Marzuk, 1999). This typology includes spousal murder-suicide, as the result of spousal jealousy or declining health of the partner(s); filicide-suicide, which involves a parent (often the mother) killing one or more children; familicide-suicide, in which entire families are annihilated; and extra-familial murder-suicide, which refers to the uncommon but highly-publicized mass murders and suicidal bombers (Marzuk et al., 1992).

Shortly after its development, Hanzlick and Koponen (1994) used the MTH classification system to classify 12 murder-suicide events. They suggested that more circumstantial information regarding murder- 
suicide events may improve the MTH system and that an alternative classification system may be needed. Several other studies have used some form of the MTH system to classify murder-suicides (Chan, Beh, \& Broadhurst, 2003; Felthous \& Hempel, 1995; Hannah, Turf, \& Fierro, 1998). However, the MTH system does not adequately incorporate psychological variables and was derived via literature review rather than through less subjective data analytic strategies. Further, the MTH typology describes motive as a function of the identity of the victims and their relationship to their perpetrator, which may be descriptive, but not explanatory.

Using 42 cases of murder-suicide reported in the New Orleans, Louisiana area from 1989-2001, Harper and Voigt (2007) devised a similar empirical classification system focusing on the relationship between the "thematic content" of the event (victim-perpetrator relationship, age, sex, race, ethnicity, and occupation) and the precipitating factors of the event (motivation, type of fatal injury, and location of event). This classification system resulted in eight types: intimate or domestic lethal violence-suicide, family annihilation-suicide, mercy killing-suicide, public killing spree-suicide, mistaken or accidental homicide-suicide, felony murder-suicide, terrorist murder-suicide, and cult mass murder-mass suicide. Of all of those mentioned, the intimate or domestic lethal violence-suicide subtype represented the majority of the cases (71\%), with family annihilation-suicide being the next most common (14\%).

One recent empirically derived classification system by Yip et al. (2009) was developed using 98 murder-suicide events in Hong-Kong. Yip et al. (2009) categorized murder-suicides by motive and victim relationship to the perpetrator using a two-step cluster analysis to derive six clusters of murder-suicide that were reduced to four major types. The first type identified was filicide-suicide (14.6\%), usually perpetrated by a female parent with a history of mental health care. This type formed the first cluster, which includes a mentally ill perpetrator. A second type described non-romantic conflict that included murder suicide incidents committed against family (cluster 2) or non-family (cluster 3) individuals (31.4\%). The third type was composed of altruistic familicide-suicides carried out by depressed males (16.9\%). A fourth type described conflicts in a loving relationship with a spouse or lover (cluster 5) or child (cluster 6) culminating in murder-suicide (37\%). The Yip et al. (2009) typology is useful in that it analyzes instances of murder- 
suicide not only based on victim-perpetrator relationship and perpetrator motive, but also examines premeditation of the event. This study was also the first to use a cluster analysis to empirically define groups of offenders.

However, the generality of this study to the United States is questionable. The most common methods of death in the Yip et al. (2009) study included "chopping with weapons and charcoal burning," whereas firearms are the most frequently used weapon in murder-suicides in the United States (Bossarte, Simon, \& Barker, 2006). Additionally, the Yip et al. (2009) study failed to address the impact of psychological variables, particularly those such as major depressive disorder and substance abuse, which are linked to violent behavior (Elbogen \& Johnson, 2009; Lewis, 2010; Pulay et al., 2008). An empirically derived classification system of U.S. murder-suicide typologies that takes into account psychological variables, and not just surface features, is needed to better classify incidents of murder-suicide.

In a unique new theory attempting to explain psychological variables related to murder-suicide, Joiner (2014) describes why "perverted virtues" might lead to murder-suicide. According to this perspective, murder-suicides usually involve the application of a twisted version of one of four interpersonal virtues-mercy, justice, duty, and glory — to the perpetrator's life and circumstances. The first of the virtues, mercy, describes a perpetrator who desires death but fears that those he/she leaves behind will be fated for "ongoing and needless misery" (p. 126). This perpetrator believes that his/her death will bring about such suffering that not only is murder of their loved ones the most appropriate choice, it's the only one that will prevent later, greater harm. Joiner's second virtue implicated in murder-suicide is that of justice, or when a perpetrator feels that a murder-suicide is necessary to right some wrong done to him or her. This perverted virtue seems to describe more than one type of offender mentioned in previous studies, and could be used to describe not only the jilted romantic partner intent on revenge for the slight, but also the mass shooter determined to rectify some wrong done by his/her employer. In the third type of perverted virtue related to murder-suicide, a sense of $d u t y$ is distorted into a belief that terminating the lives of others, often family members, is necessary to save them from the burden of inheriting the perpetrator's troubles. This is different, Joiner describes, from a mercy killing, because the motive is not primarily mercy towards 
others, but a desire to end one's suffering while practicing duty to another. Joiner's last virtue, glory, is implicated in murder-suicides in which the perpetrator seeks heroic glory, or enduring social recognition, for the act. This type often could be applied to mass murder-suicide perpetrators, like Columbine shooters Eric Harris and Dylan Klebold, who killed 13 people before taking their own lives, and who (in Harris' words) did so ensuring they could be "remembered forever" (Joiner, 2014, p. 172). These teenage boys committed this act not because they sought justice against their peers, but because they wanted to exceed the death count of Timothy McVeigh, who was responsible for 168 deaths in the 1995 Oklahoma City bombing.

\section{Military Murder-Suicide}

Much research has focused on murder and suicide separately, but very little has been accomplished in the study of the two together. Indeed, in the words of Stack (1997), "research on homicide has neglected suicide and research on suicide has neglected homicide" (p. 435). Of those studies that have focused on murder-suicide specifically, no consideration has been given to current or former military members. Many researchers have examined risk for violence and/or domestic disturbance among veterans (Buncombe, 2002; Byrne \& Riggs, 1996; Marshall, Panuzio, \& Taft, 2005; McCarroll et al., 2003; Orcutt, King, \& King, 2003; Prigerson, Maciejewski, \& Rosenheck, 2002; Strauss \& Gelles, 1990) but none have explored the relations between group characteristics (combat exposure, frequent deployments, and interpersonal stress) and the risk to complete murder-suicide. Veterans make up nearly $10 \%$ of the U.S. adult civilian population and those currently serving about $1 \%$ (U.S. Census Bureau, 2008). By statute, a veteran is defined as a "person who served in the active military, naval, or air service, and who was discharged or released therefrom under conditions other than dishonorable" (38 U.S.C. § 101(2); 38 C.F.R. § 3.1(d)). Historically, there has been some fluctuation in the policy dictating the required length of service to be considered a veteran, and before 1980, there was no official time in service requirement to qualify for military benefits (Scott, 2012).

However, the definition used today by the U.S. Department of Veteran Affairs states that only an individual "who is activated for federal military service and serves 24 months of continuous active duty or the full period of activation" is qualified to receive Title 38 military benefits (Scott, 2012, p.1). This recent 
distinction takes into account the service of those in the National Guard or Reserve components, who are often activated for a much shorter period of time than their active-duty peers, and therefore, includes the men and women of the Reserve components. Using the verbiage from this policy, a veteran is an individual who has completed a period of active duty and who has separated from the armed services under honorable conditions. To receive healthcare from a Veterans' Affairs (VA) medical center, one must be eligible for Title 38 benefits; thus, samples of veterans receiving care from a nearby VA center used in previous studies (Lemaire \& Graham, 2011; Nademin et al., 2008) are assumed to meet the aforementioned definition, even though it is usually not stated explicitly.

\section{Military Suicide}

Though veterans make up only $10 \%$ of the American population, they account for $20 \%$ of suicides in the U.S. annually (Blumenthal, Maliha, \& Mathews, 2012). On average, one suicide a day occurs in the military, and the number of service members who took their lives this year has surpassed the number killed in combat -indicating a more than 30-year high (Thompson \& Gibbs, 2012). Indeed, the 349 military suicides recorded by military officials in 2012 exceeded the 301 of the previous year and far surpassed the Pentagon's own internal predictions of 325-demonstrating a "dark trend" that is expected to continue to rise in the following years (Burns, 2013, p. 1).

Many researchers have posited that exposure to combat may be directly related to risk for suicide, but the specific triggers for suicide are unique to each service member. A report from Time magazine in July 2012 listed several "stresses layered on by war," including frequent deployments, tough choices to make, separation from loved ones, loss of fellow service members, battle injuries, and the constant presence of painful and/or lethal environmental elements (Thompson \& Gibbs, 2012, p. 25). However, other statistics indicate that combat exposure alone cannot account for the trend. Nearly a third of suicides from 2005-2010 were among military members that had never deployed, and fewer than $50 \%$ had deployed only once. Young, enlisted troops are more likely than older demographics or the officer corps, and males more likely than females, to complete an act of suicide (Thompson \& Gibbs, 2012). Historically, military rates have 
remained comparable to civilian rates, but in the last ten years, the numbers of military members lost to suicide has skyrocketed.

No program, outreach or initiative has been successful at stopping the surge of suicides (Thompson \& Gibbs, 2012), but several theories have emerged to attempt to explain what puts military members at greater risk. The fact that many veterans who have completed a suicide have never deployed stands contrary to studies suggesting that combat exposure directly affects suicidal ideation and the ability of veterans to successfully complete a suicide (Bryan, Cukrowicz, West, \& Marrow, 2010). To attempt to explain the complex relations between military training, combat exposure, and deployment stressors, new research has emerged that suggests that combat experience precipitates a sequence of psychological variables leading to increased suicidality. After studying negative mood, social support, and Post-Traumatic Stress Disorder (PTSD) symptoms in Army National Guard soldiers, Griffith (2012) found that combat exposure had an indirect relation to post-deployment suicidality mediated by PTSD symptoms and negative mood. Furthermore, PTSD symptoms showed no direct relationship to suicidality, but showed indirect effects through negative mood. Most interestingly, the majority of soldiers in the sample who were not suicidal before deployment remained non-suicidal after deployment. In his sample, most of the soldiers who reported suicidal ideation after deployment had also reported a history of suicidal ideation before deployment - suggesting that suicidality is relatively persistent, and that its relation to PTSD and negative mood is mediated by an individual's personal disposition and social support post-deployment (Griffith, 2012). This indirect relation has recently been supported by others (Guerra \& Calhoun, 2011; Krysinka \& Lester, 2010), and increased focus placed on the assessment of pre-military stressors and individual characteristics (Gradus, Shiperd, Suvak, Giasson, \& Miller, 2013) in order to understand more completely the links between the variables underlying suicidal risk.

\section{Military Violence and Harm to Others}

Mirroring the pattern of deaths by suicide, the rates of crimes committed by military members has also increased in recent years, with $10 \%$ of state prisoners in the U.S. reporting military service (Bureau of Justice Statistics, 2004). Recent estimates from abroad echo these percentages, with approximately $9 \%$ of 
English and Welsh prisoners having served in the armed forces in 2009 (Napo, 2009). Perhaps even more striking is the percentage of these veteran inmates currently serving time for violent offenses. In the U.S., $57 \%$ of veteran prisoners were considered "violent offenders," as compared to $47 \%$ of the civilian prisoners. Both in the U.S. and U.K., veterans are less likely than the general population to offend, but more likely to be incarcerated for violent and sexual offenses (MacManus \& Wessely, 2012).

Although research is emerging from the recent wars in Iraq/Afghanistan, much of the data on general violence committed by military veterans has been obtained using samples of veterans from previous conflicts. Yager, Laufer, and Gallops (1984) found that though deployment to Vietnam was not associated with increased rates of self-reported arrests/convictions, having been exposed to combat while deployed was. These findings, while significant, might have been under-representative of the true rate of violent acts committed by veterans, as the researchers did not include in their sample veterans currently in prison, and relied solely on self-report of criminal behaviors. Similarly, Black et al. (2005) found that even after adjusting for variables such as education, income, mental health characteristics and previous antisocial behavior, direct combat experience was significantly associated with incarceration for violent offenses after the Gulf War.

As military personnel have begun to return from the Middle East, some researchers have focused on the relation between combat exposure, antisocial behavior, and increased aggression. In a study originating from the Walter Reid Institute of Army Research, soldiers were queried about the number of times they got into a physically violent altercation that resulted in hitting someone. Approximately $20 \%$ reported hitting someone one or more times in the last month, with little change in frequency from three to 12 months postdeployment (Thomas et al., 2010). In a sample of Marines who had been deployed to Iraq or Afghanistan between 2002 and 2007, combat exposure was positively associated with antisocial behavior and increased aggression after adjusting for a variety of potential confounding variables (Booth-Kewley, Larson, HighfillMcRoy, Garland, \& Gaskin, 2010). Other researchers have found similar ties between specific combat experiences, like killing another person, and greater risk-taking propensity upon returning home (Killgore et al., 2008; Vaughan, 2006). 
A specific area of great concern for not only society but for military families is intimate partner violence (IPV). Interest in the difficulties faced by military families when it comes to IPV has increased in recent years, especially in the U.S., due in part to well-publicized homicides related to domestic violence. Research focusing on veterans involved in IPV returning from Iraq or Afghanistan revealed that 3.5\% initially reported concerns/thoughts of interpersonal aggression, but over the following six months, this increased to 14\% (Milliken, Auchterlonie, \& Hoge, 2007). In fact, the rates of IPV among active duty servicemen and veterans are, at any given time, up to three times higher than those found in the general population (MacManus \& Wessely, 2012). These dramatic differences from what might be expected from the non-veteran population have been attributed by many researchers to combat exposure, in that veterans are exposed to violence in such a manner that they come to view violence as an acceptable outlet of expression (Gimbel \& Booth, 1994; McCarroll et al., 2010).

\section{Specific Study Goals}

Given these trends in suicide and interpersonal violence, it was hypothesized that military (current and former) perpetrators of murder-suicide would be different from civilian perpetrators in several important ways. In accordance with previous research on domestic violence in military families, it was predicted that military perpetrators would demonstrate a higher frequency of incidents of IPV compared to a civilian matched control (MacManus \& Wessely, 2012; Milliken et al., 2007). Military murder-suicide perpetrators were also predicted to be significantly younger than civilian perpetrators, based on recent surges in suicide in younger military members (Thompson \& Gibbs, 2012). No researchers to date had examined military members as a specific risk group for murder-suicide, and as such, it was likely that other significant differences existed between military and civilian perpetrator groups. The goals of this study were:

1) Compare demographics of military to civilian murder-suicide perpetrators.

2) Compare behavioral health of military versus civilian murder-suicides.

3) Compare event-contextual characteristics of military to civilian murder-suicide. 
4) Using logistic regression, determine which factors predict membership to either the military or civilian murder-suicide perpetrator groups.

The National Violent Death Reporting Service (NVDRS) database was used to accomplish these goals. Since 2002 the NVDRS has collected data on more than 20,000 violent deaths from 18 states (Logan et al., 2008; Barber, Azrael, \& Hemenway, 2013). The NVDRS collects and combines information from death certificates, police reports, crime laboratories, and medical reports to provide a comprehensive picture of violent deaths including homicides, suicides, and accidental firearm deaths. Despite developing an oftencited categorical system, Marzuk et al. (1992) advocated for the development of a "national surveillance network" that would enable the "conceptualization and validation of a taxonomic system" of murder-suicide (p. 3183). Today, the NVDRS database contains the most extensive records of murder-suicide incidents and related variables, and is "uniquely equipped to study [murder-suicide]" (Bossarte et al., 2006). These data may enable researchers to determine which aspects of murder-suicide may be more common in military populations, potentially permitting earlier intervention.

\section{Method}

\section{Data Source}

The methods for this study closely resembled the methods used in Logan et al. (2008). Data collection will begin using information on cases of military murder-suicide as reported by the NVDRS. The NVDRS began collecting information on violent deaths in 2002, and included data from six states (Massachusetts, Maryland, New Jersey, Oregon, South Carolina and Virginia.). In 2003, seven more states were added (Alaska, Colorado, Georgia, North Carolina, Oklahoma, Rhode Island, and Wisconsin.). The sample is now 18 states after the addition of California, Kentucky, New Mexico, Utah, Michigan and Ohio in 2004 and 2009 (CDC, 2013). Data collection is statewide, with the exception of California, in which data are only collected from four counties (Los Angeles, Riverside, San Francisco, and Santa Clara). For the purposes of this study, access was granted to perpetrator data from years 2002-2010. 


\section{Participants}

Information was requested from all participating states on all suicides, homicides, deaths involving legal intervention, unintentional firearm deaths, and deaths for which manner of death was undetermined. Access was granted to medical examiner and coroner reports, police/law enforcement reports, and toxicology reports.

Murder-suicide was operationally defined as "a suicide incident where the perpetrator committed at least one homicide within one calendar day prior to his or her suicide death" (Logan et al., 2008, p. 1057). This definition was extended to include incidents where the perpetrator committed at least one act resulting in a homicide within one calendar day of his/her death. This subtle change allowed for inclusion of victims who were fatally wounded by the perpetrator, but who did not die until more than one calendar day since the perpetrator's suicide had elapsed. Within the data set, victim status was described as $1=$ victim, 2 $=$ perpetrator , and $3=$ victim and perpetrator (or individuals who killed others and then died in the same incident). Of over 110,000 violent deaths in this time frame, a sample of 1,519 incidents in which an individual both killed someone else and died were identified in this manner $(3=$ victim and perpetrator $)$. However, this victim-perpetrator code also classified mutual homicides (e.g., a shootout between two neighbors during a disagreement) as murder-suicide, so great care was taken to review each case and rule out any cases not meeting the definition of murder-suicide described earlier. Murder-suicide incidents that did not meet a 24 -hour time definition (i.e., the suicide was completed more than 24 hours after the murder was perpetrated) were also removed from the data set. Female murder-suicide perpetrators were also excluded from this analysis, as men and women often have different circumstances and preceding events (Marzuk et al., 1992) and in this sample, there were too few females to examine $(n=3)$.

Once all murder-suicide cases were identified, designation of an individual as current/former military was completed using a variable pre-coded by NVDRS administrators: Has the person served in the U.S. Armed Forces, $0=y e s, 1=n o$ ). Military status was based on the information received from police and investigative reports associated with the records of each murder-suicide perpetrator and yielded a sample of 284 military perpetrators. This designation was either decided by the law enforcement officers involved 
with the case or reported by witnesses or family members, and does not necessarily correspond with Title 38 definition. Though it is acknowledged that the definition supplied by the U.S. Department of Veteran Affairs mentioned earlier is the official one, it is possible that these records might not follow this classification. After screening the military sample to ensure all cases met the study definition for murdersuicide provided earlier, a final sample of military murder-suicide perpetrators was selected $(n=259)$. A civilian group matched by gender $(1=$ male $)$ was randomly selected from the larger data set $(n=259)$.

Murder-suicide incidents were further categorized on the basis of the rated motive for the murder, as determined by information acquired from statements from the victim's neighbors, family, friends, or other acquaintances. Initially, motive was conceptualized using the MTH typology (Marzuk et al., 1992). However, when it was determined that this typology did not seem to explain the perpetrator's motivation, but rather the relationship between the perpetrator and his victims, the authors created a new coding system for motive using a small group of murder-suicide cases. Using a coding manual developed by the authors in these pilot analyses, only one motive per incident was designated $(1=$ jealousy/anger related to relationship dissolution, $2=$ benevolence, $3=$ non-romantic conflict, $4=$ depression $/$ psychache, $5=$ delusional thinking/psychosis, and $6=$ unknown). For each case, information in the police narrative and medical examiner report was used to rate which of these motives was most applicable, going in order and eliminating each motive until one was selected that most accurately represented the case.

Cases with a motive of jealousy/anger related to relationship dissolution involved a recent termination of a real or perceived romantic relationship, resulting in one of the romantic partners feeling jealous or angry and completing the murder-suicide as a means of retaliation. Motive was coded as benevolence if the perpetrator's primary motive was to end the suffering of a loved one; but for the failing health of a loved one, the murder-suicide would not occur. Cases with a motive of non-romantic conflict included a conflict between individuals not directly relating to the dissolution of a romantic relationship, with the conflict often related to money, perceived disrespect, frustration, or goal blocking. A motive of depression/psychache was coded if there were significant external stressors present, like financial strain or mental health concerns, and if the primary goal was to alleviate the suffering of the perpetrator. The 
delusional thinking/psychosis motive was coded if there was explicit evidence of psychosis, hallucinations, or other extreme misperception/delusions, and if the primary motivation for the murder-suicide was related to this presentation of symptoms. Finally, if motive could not be reasonably surmised from the police narrative/medical examiner information, a case was coded as having an unknown motive. For a more detailed description of each motive, including exclusion criteria, see Appendix A.

Victim-perpetrator relationship, a variable pre-coded by the NVDRS, was not consistently entered throughout the dataset, so this variable was re-coded using the NVDRS designators (victim was a: $1=$ spouse/intimate partner, 2 = parent, $3=$ child, $4=$ other relative, $5=$ additional intimate partner (i.e., wife's boyfriend), 6 = acquaintance/friend, $7=$ stranger, $8=$ law enforcement officer, $9=$ unknown). If there was more than one victim, the victim designated by NVDRS as primary was used to code the motive.

To ensure coding accuracy and highest inter-rater reliability, several pilot coding rounds were conducted with three independent raters. A total of 300 cases were coded between the three raters, with an overall kappa of 0.80 . Once inter-rater reliability was established, the rest of the cases were coded, with a final kappa of 0.75 . All cases were then independently coded for motive by two of the three raters; if a disagreement occurred, the third rater coded the case and finalized the motive.

\section{Analysis}

Military versus civilian murder-suicide perpetrators were compared across variables by first calculating frequency distributions of demographic factors, life events, behavioral health, and contextual variables hypothesized to be risk factors for murder, suicide, or murder-suicide. Chi-squared analyses were conducted to compare whether these variables were significantly different for military versus civilian murder-suicide perpetrators. Cell sizes were small for many variables, so Fisher's exact test was used where appropriate to assess statistical significance for categorical variables (Logan et al., 2008). Due to the large number of comparisons, a Bonferroni correction was applied to the confidence level to correct for Type 1 error.

Logistic regression was conducted to identify the most parsimonious model predicting membership to either the military or civilian perpetrator groups. Variables identified as significant during 
univariate analyses were selected for stepwise entry into SPSS. A continuous age variable, instead of the previously coded age aggregate, was entered in Step 1, along with marital status and race. Instead of loading marital status and race into the model as a multi-level categorical variables, these variables were recoded as dichotomous variables to reduce the number of total comparisons. Marital status was re-coded into a "never married" dichotomous variable $(0=$ currently/previously married, $1=$ never been married $)$ and race into a "White" dichotomous variable $(0=$ not White, $1=$ White $)$. Instead of a multi-level motive variable, each motive $(1=$ jealousy/anger related to relationship dissolution, $2=$ benevolence, $3=$ conflict , and $4=$ depression/psychache $)$ was converted into a dichotomous variable $(0=$ no, $1=y e s)$. Cases including the delusional/psychosis motive $(n=5)$ and unknown motive $(n=91)$ were removed due to either small cell sizes or lack of clinical utility. Other cases including a marital status of single, not otherwise specified $(n=2)$ or marital status unknown $(n=6)$ were also removed due to small cell sizes, to yield a smaller sample of 200 military and 214 civilian murder-suicide perpetrators to be used for the regression. Finally, correlation coefficients for these variables were calculated to assess for multicollinearity before conducting the regression. Bonferroni adjustments were made to control for Type I error (see Table 7). None of the coefficients were highly correlated $(r>.80)$, suggesting that multicollinearity was not a problem in this data set.

\section{Results}

Because cases involving military perpetrators were extracted from the larger dataset and cases involving civilian perpetrators were randomly selected to form a comparison group with equal percentages of military and civilian perpetrators, the resulting dataset was determined to be unrepresentative of murdersuicide in general. Thus, information regarding the total demographic characteristics of all perpetrators in the sample was separated and is detailed in Appendix B. Of the 1,519 total murder-suicides in the data set, 259 were military murder-suicides. This percentage, which is approximately $17 \%$, is less than expected, considering that military members account for roughly $20 \%$ of suicides annually in the United States (Blumenthal et al., 2012; Thompson \& Gibbs, 2012). 
Table 1 summarizes the demographic characteristics of military and civilian murder-suicide perpetrator subgroups. Military perpetrators of murder-suicide were older than the civilian control group, with significantly more military perpetrators aged 55 years and older ( $51.8 \%$ versus $16.9 \%$, respectively), $\chi^{2}$ $(5)=93.61, p<.001$, with a mean age of 57.05 years $(S D=18.06)$. Civilian perpetrators, on the other hand, were more often 44 years of age or younger, with a mean age of $41.56(S D=13.72)$. An independent t-test revealed that military perpetrators were significantly older than civilian perpetrators, $t(516)=-10.99$, $\mathrm{p}<.001$, with a very large effect size of $d=.97$. The majority of murder-suicide perpetrators were identified as White, but military perpetrators were more often White $(80.3 \%)$ than their civilian counterparts $(73 \%)$. Further, the military perpetrator sample had significantly fewer individuals that identified as American Indian or Pacific Islander than the civilian perpetrator sample, $\chi^{2}(4)=18.49, p<.001$. Military perpetrators were significantly more likely to be married (38.6\%) than were civilian perpetrators (27.8\%), and a significant proportion of civilian perpetrators had never been married compared to military perpetrators $\left(26.6 \%\right.$ and $11.6 \%$, respectively); $\chi^{2}(6)=26.7, p<.001$. Information about education was limited, with data regarding highest education achieved available for only $41.5 \%$ of perpetrators. Due to these missing data, meaningful differences between military and civilian perpetrators could not be determined.

Victim relationship to the perpetrator and primary motive are displayed in Table 2. Similar to previous research, most of the victims were current or former spouses or intimate partners, with percentages of $78.4 \%$ for military perpetrators and $73.4 \%$ for civilian perpetrators. The next most common victims were friends or acquaintances for $6.9 \%$ of cases involving military perpetrators and $7.3 \%$ involving civilian perpetrators. Children of the perpetrators were identified as the primary victims in $5 \%$ of military perpetrator cases, and in $3.9 \%$ of civilian perpetrator cases. Strangers were the victims in only $1.2 \%$ of military cases and in none of the cases involving civilian perpetrators. None of these differences in primary victim between military and civilian perpetrators were statistically significant.

Although there were no differences in primary victim, there were significant differences in motive between military and civilian perpetrators. Significantly more military than civilian perpetrators 
demonstrated the depression/psychache motive (20.8\% versus $9.7 \%$, respectively), and significantly more civilian perpetrators exhibited the jealousy/anger related to relationship dissolution motive (44.4\% versus $29 \%$, respectively), $\chi^{2}(5)=28.58, p<.001$. Military $(21.6 \%)$ and civilian $(27.8 \%)$ perpetrators also completed a murder-suicide due to conflict-related feelings of anger or frustration, but these percentages were not significantly different. Motive could not be ascertained for $20.5 \%$ of military perpetrators and $14.7 \%$ of civilian perpetrators due to inadequate information in the NVDRS data set.

Perpetrator behavioral health characteristics are shown in Table 3. Although a history of suicide attempts was identified for $3.5 \%$ of cases involving a military perpetrator and $2.7 \%$ of those involving civilian perpetrators, the groups did not significantly differ on these characteristics. Military perpetrators (14.3\%) were more likely to report physical health complaints than were civilian perpetrators $(2.3 \%), \chi^{2}(1)$ $=24.37, p<.001$. Civilians displayed more symptoms of current substance abuse $(9.3 \%$ versus $4.6 \%)$ than did military perpetrators, but this association was only a trend and not significant, $\chi^{2}(5)=4.3, p=.056$. Civilians were more often suspected of alcohol intoxication ( $27 \%$ versus $17.8 \%), \chi^{2}(2)=7.83, p=.02$. Military perpetrators (25.9\%) left notes more frequently than did civilian perpetrators $(18.9 \%)$-a trend that approached significance, $\chi^{2}(1)=3.6, p=.073$.

Table 4 summarizes the event and contextual factors for civilian and military murder-suicide perpetrators. Military perpetrators were more likely to complete the murder-suicide at a home or apartment ( $66.4 \%$ versus $53.7 \%$ of civilians), and civilians more likely to complete the act at a location outside of the home $(44.8 \%$ versus $30.9 \%), \chi^{2}(2)=10.93, p=.004$. No significant differences emerged regarding weapon used by military versus civilian perpetrators, perhaps due to the infrequent usage of weapons other than firearms for both groups. Interestingly, significantly more civilian $(77.6 \%)$ than military (68.7\%) perpetrators experienced intimate partner problems proximal to the murder-suicide, $\chi^{2}(1)=5.2, p=.029$. The logistic regression was conducted using the likelihood ratio method to determine whether demographic factors (age, White ethnicity, never married) motive (jealousy/anger related to relationship dissolution, benevolence, conflict, depression/psychache), behavioral health variables (physical health problem, current substance abuse, suspected intoxication, left suicide note), and contextual-event factors (at 
person's home, intimate partner problem) uniquely predicted membership to either military or civilian murder-suicide perpetrator groups. The results of the likelihood ratio test are presented in Table 5 and show that the final model provided a better fit for the data than the intercept-only model, $\chi^{2}(13)=99.5, p<.001$, Nagelkerke $R^{2}=.285$. The only individual regression coefficient that was significant in the model was age $(B=.054, p<.001)$, although physical health problems approached significance $(B=-.992, p=.064)$. This model correctly classified 166 of $214(77.6 \%)$ civilian and 125 of 200 military (62.5\%) murder-suicide perpetrators. The overall correct classification was $70.3 \%$-a significant improvement over chance. These results indicate that age has an overwhelming influence on prediction of group membership, suggesting that group membership could be better explained by including only age as a predictor in later models.

A second regression was conducted with only age to determine whether doing so would lead to an increase in correctly classified group members. The age-only model provided a better fit than the interceptonly model, $\chi^{2}(1)=85.21, p<.001$, Nagelkerke $R^{2}=.248$, and correctly identified 161 of $214(75.2 \%)$ civilian and 122 of $200(61 \%)$ military perpetrators. The overall correct classification was $68.4 \%$, which was a significant improvement over chance, but poorer than the first model including all variables.

To better understand effects of these secondary variables without the influence of age, a third regression was undertaken with age removed as a predictor and all other variables entered in the order previously described. The results of this regression are shown in Table 6. Non-significant variables were removed until the final model included only those variables that significantly contributed to the predictive ability of the final model. Here, physical health problems $(B=-1.61, p=.001)$, never having been married $(B=.822, p=.003)$, and a motive of depression/psychache $(B=-.6, p=.041)$ all uniquely predicted status as either a civilian or military perpetrator. Substance abuse was not significant $(B=.798, p=.065)$. With the exclusion of age as a predictor, this model correctly predicted 192 of 214 (89.7\%) civilian and 63 of 200 (31.5\%) of military perpetrators, with a total correctly classified percentage of $61.6 \%$. This model, including those variables deemed "secondary predictors," provided a better fit than the intercept-only model, $\chi^{2}(1)=47.7, p<.001$, Nagelkerke $R^{2}=.145$. Though the "secondary predictors" model did provide 
insight into variables potentially affecting group membership, this model did not offer an improvement over the model including age as a predictor.

After these regressions were completed, additional diagnostics were conducted to assess for undue variable influence and potential outliers. Analysis of the studentized residuals, standardized residuals, and deviance statistics of the data indicated that all had absolute values of 2 , suggesting that there were no individual points fit poorly by the model. Visual inspection of Cook's distance and DFBeta values revealed no cases with absolute values greater than 1.00 , indicating that none of the data points exerted an undue influence on the model.

Given the significant differences in age between military and civilian murder-suicide perpetrators, post-hoc analyses were conducted to determine if this same age difference (i.e., military perpetrators being much older) was also exhibited in suicide-only perpetrators. To achieve this aim, two matching samples of suicide-only perpetrators $(n=259)$ were taken from the larger sample of all violent deaths with suicide indicated as the manner of death. Mean age of suicide completers was calculated for each sample and compared to the mean ages of murder-suicide perpetrators for each group in an independent $t$-test. Results are shown in Table 8 . Similar to military murder-suicide perpetrators, military suicide completers $(M=$ 57.45 years, $S D=17.37)$ were significantly older than their civilian counterparts $(M=43.01$ years, $S D=$ $16.39), t(516)=-9.73, \mathrm{p}<.001, d=.86$, suggesting that the age difference observed in earlier analyses was not an effect limited to perpetration of murder-suicide only.

To determine if motives that were significantly different for military and civilian perpetrators (i.e., jealousy/anger related to relationship dissolution and depression/psychache) were related to this age effect, percentages of both motives was calculated for each age aggregate. Percentages of cases involving the jealousy/anger motive by age aggregate for military and civilian perpetrators motive is shown in Figure 1. The jealousy/anger motive was exhibited more frequently by civilian $(n=115)$, rather than military $(n=$ $75)$, perpetrators, and was most common for civilians aged $25-54$ years $(78.1 \%$ of all cases with this motive). This motive, though common for younger civilians, decreased in occurrence as civilians aged, dropping dramatically for perpetrators aged 55 or older. Fewer military perpetrators completed a murder- 
suicide due to this motive, and those who did were slightly older than civilian perpetrators (35-55 years). Like civilian perpetrators, the percentage of perpetrators with the jealousy/anger motive generally decreased with age, but starting at ages 45-54 years, military perpetrators demonstrated jealousy/anger as a motive more frequently than civilians $(29.3 \%$ versus $21.7 \%)$. The percentages of cases involving the depression/psychache motive by age aggregate for both groups is shown in Figure 2. Compared to the frequency of the jealousy/anger motive $(n=115)$, frequency of the depression/psychache motive was low for civilian perpetrators $(n=25)$. The percentage of civilian perpetrators with this motive was highest for adults ages 35-44 years (28.6\%), and generally fluctuated for adults of all ages. For military perpetrators, the depression/psychache motive was exhibited very rarely in younger adults ages $(0 \%$ for the $18-24$ years and $1.8 \%$ for the $25-34$ years aggregates), but rose steadily throughout adulthood, peaking sharply after 5564 years. For military perpetrators ages 65 years and above, the percentage of perpetrators with the depression/psychache motive (61\%) was more than three times the percentage of the same motive for civilians of the same age $(16 \%)$.

\section{Discussion}

This study examined the differences between military and civilian murder-suicide perpetrators using demographic, behavioral health, and event-contextual variables obtained from the National Violent Death Reporting System (NVDRS). First, findings showed that military perpetrators were significantly older than their civilian counterparts, with a mean age of 57.05 years that was significantly different from the civilian mean age of 41.56 years. Military perpetrators were identified as White more often than civilians and were more likely to be married currently or in the past.

Second, military perpetrators more often completed a murder-suicide due to a motive of depression/psychache, where civilians due to feelings of jealousy or anger related to relationship dissolution. Third, military perpetrators exhibited more physical health problems than civilians, and civilians had greater incidences of suspected intoxication. Fourth, military perpetrators were more likely than civilians to complete the murder-suicide at home, versus a location outside the home (e.g., a neighbor's 
home, the perpetrator's place of employment, etc.). Contrary to prediction, military members were less likely than civilians to have a current intimate-partner violence problem. Finally, the results of a logistic regression revealed that poor physical health, a motive of depression/psychache, a current or previous marriage, and the absence of current substance abuse uniquely predicted identification of the perpetrator as a current or former military member. Poor physical health and having a current or previous marriage also uniquely predicted membership to the military group, but it is suspected that these findings may be at least partially attributable to previously described effects of age.

Previous research has described a particular kind of murder-suicide perpetrator who experiences overwhelming feelings of depression, hopelessness, and despair, and who will often kill his/her own family member(s) to lessen their burden and prevent ongoing harm from coming to them (Harper \& Voigt, 2007; Joiner, 2014; Marzuk et al., 1992; Yip et al., 2009). In this sample, this motive (depression/psychache) was documented more frequently in the military, rather than civilian, perpetrator sample. Though military perpetrators also completed murder-suicides for reasons similar to their civilian peers (jealousy/anger related to relationship dissolution, anger/frustration related to conflict), the number of perpetrators doing so due to an inability to cope with their own stressors, like failing health, depression, and financial strain, more than doubled that of civilians (54 versus 25 perpetrators). This relation held true even when comparing older military perpetrators to older civilian perpetrators. In a sample of perpetrators aged 41 years or older, the rate of military perpetrators demonstrating the depression/psychache motive was still significantly higher, more than doubling that of civilians (51 versus 17 , respectively). Though not indicated in previous research, these results seem to suggest that the depression/psychache motive is seen more commonly in older adults, and because the military sample was comprised of mostly this demographic, this ratio led to a predominance of this motive for military perpetrators.

This imbalance of age also raises some interesting questions. In opposition to the prediction that military murder-suicide perpetrators would be significantly younger than civilian perpetrators due to recordhigh military suicide rates for young military members (Thompson \& Gibbs, 2012), the average age for military perpetrators was 57 years, compared to the mean civilian age of 41 years. These surprising results 
are contrary to the earlier prediction that military murder-suicide perpetrators would be significantly younger than civilian perpetrators, and seems to be related to the finding that military suicide completers in this sample were also significantly older than civilians ( 57 versus 43 years, respectively). Here, the question surrounds the concept of protective factors-what is it about previous military service that might serve to buffer against not just murder-suicide, but suicide as well, until much later in life?

Previous research on protective factors for suicide indicates that many factors identified as protective for civilians, including family and social support, religious affiliation and participation, and current mental health treatment, may also serve to protect military members from completing a suicide (Nock et al., 2013). Protective factors specific to the military include additional social support from the member's unit, perception of supportive leadership, and strong peer-to-peer (i.e., soldier to soldier) relationships. Indeed, the perception of social support specific to one's military unit has been shown to buffer against the negative effects of stress, the development of PTSD and other psychological disorders, and suicidality altogether (Nock et al., 2013). The impact of military unit cohesion is so powerful that it can often lead to a the perception of enhanced combat readiness and the desire to stay in the armed services longer, which could create a cycle of exposure to positive interactions between the military member and their brothers in arms (Griffith, 2012; Halverson, Bliese, Moore, \& Castro, 1995).

Other studies of military protective factors include a focus on psychological factors such as stoicism, autonomy, and resilience. In their review of previous research, Nock et al. (2013) postulated that traits like these, which are often cultivated and fostered in military training, could potentially buffer military members from the detrimental effects of stress, thereby decreasing suicidality. Bryan, Jennings, Jobes, and Bradley (2012) refer to this cluster of traits "mental toughness," and describe how, in the face of remarkable physical and emotional pain or adversity, military members are taught to attend to their wounds, whether physical or emotional, and "shake it off" so that they can return to the mission at hand. When it comes to murder-suicide, a predominance of these protective factors may serve to protect its members from succumbing to self-harm or harm of others while currently serving in the military—but once these individuals separate from the service, risk may begin to rise. 
When military members do resume their lives outside of the armed services, values learned in the service, like duty to others, may evolve into a justification of sorts for an act of murder-suicide. According to Joiner (2014), duty involves "the honorable discharge of one's perceived responsibilities to others"- $\mathrm{a}$ definition not at all dissimilar to the way the word is defined in the Army's "Seven Core Values." In this set of standards designed to indoctrinate new Soldiers and educate them on the Army's expectations, recruits are told that duty means more than fulfilling your own obligations, but that it also applies to fulfilling your duties to others. In Joiner (2014), the typical perpetrator of murder-suicide related to a perversion of duty is an older, married, male adult who decides to end his own life first, then his spouse's to prevent his obligations from falling to her-which looks, interestingly, very much like the typical military perpetrator in this sample. Civilians, on the other hand, perpetrate significantly more murder-suicides with motive classified as jealousy/anger related to relationship dissolution. These differences in perverted virtues of murder-suicide might explain the difference in primary motive for military versus civilian murder-suicide perpetrators. Military perpetrators, who have been exposed to and expected to exemplify the concept of duty, may be more likely to kill family members before killing themselves because they want to prevent loved ones from the burden they believe they will inherit upon their death. Civilians, according to this perspective, might do so for the purposes of seeking justice for the perceived wrong exacted on them by their romantic partner.

It is clear that much of what we know about suicide also applies to murder-suicide, and murdersuicide within a military sample is no exception. Joiner (2014) mentions that one aspect of murder-suicide that is key to identification of high-risk individuals is that suicide is primary, or the driving factor behind the events that follow. A perpetrator of murder-suicide makes a plan to complete his or her own suicide, and the deaths of others are considered secondary to the overarching goal of ending one's life. With regard to prevention of murder-suicide, then, it follows that there may be no need for a separate interventions, because, as is mentioned in Joiner (2014), "suicide prevention subsumes murder-suicide prevention" (p. 193). Similar to suicide risk assessment in clinical populations, risk for military murder-suicide could be assessed by attending to risk factors shared by the two phenomena. Risk assessment questions designed to 
elucidate information on murder-suicide might focus on not just suicidal ideation, but homicidal ideation as well. Given the risk factors highlighted in this study, questions designed to collect information on physical health disparities, depression and burdensomeness, and influence of external stressors might also prove beneficial. Additional assessment designed to reveal an individual's beliefs, or virtues, on the topic of suicide or harm to others (e.g., duty, mercy) might also serve to highlight risk for murder-suicide. When these virtues are identified and elevated risk established, cognitive-behavioral therapy, with a focus on addressing and challenging these distortions in thought, would be ideal (Joiner, 2014).

As important as identification of risk factors and virtues related to murder-suicide is, there is the possibility that current interventions designed to decrease suicidal risk may not apply as cleanly to military members. Social support interventions designed to increase contact with social reinforcers for those considered at risk for murder-suicide might not prove as efficient for those who are married or married with children — which presents potential limitations for military members, as many in this sample were currently married. Older veterans, who (according to recent estimates) make up approximately one-seventh of all homeless individuals (Khadduri, Culhane, \& Cortes, 2010), may have difficulty accessing medical and psychological services, and, in the light of recent public attention to suicide in younger veterans, may not be the subject of major prevention efforts. Current therapeutic techniques that do not focus on challenging beliefs increasing risk for murder-suicide (e.g., duty) may temporarily decrease suicidal risk, but will not decrease the likelihood that if risk should later increase, that the individual will not complete a murdersuicide based on these beliefs.

This study was the first to examine military murder-suicide and to compare this phenomenon with civilian murder-suicide. Indeed, this study is one of few examining military violence, and the only one (to this author's knowledge) describing military murder, even if indirectly. Other strengths include a large sample of murder-suicide offenders, including an exhaustive sample of military murder-suicide perpetrators from 18 states across the United States over a six-year time span. Most other studies of murder-suicide have been either theoretical in nature (Marzuk et al., 1992) or concentrated on a small, potentially unrepresentative sample, like Hong Kong (Yip et al., 2009), Tasmania (Haines, Williams, \& Lester, 2010), 
or the Netherlands (Liem, Postulart, \& Nieuwbeerta, 2009). In studies employing a typology of offenders, motive was often confounded with victim-perpetrator relationship — potentially misrepresenting the true motives of murder-suicide perpetrators and perhaps ignoring individual differences.

Despite the strengths this study offers, there are some limitations warranting further discussion. Motive and victim relationship to perpetrator were variables coded upon receipt of the data, and were based on police narratives, medical examiner reports, and family and witness statements. It is possible that information may have been missing from these reports that could have led to a re-classification of these variables. Other variables, like previous suicide attempts or history of mental health treatment, were not always present and may have been coded inconsistently by NVDRS system operators, perhaps limiting conclusions about their significance with regard to this population. Veteran status was based on confirmation by the perpetrator's family, by what information was readily available in his records, or by self-report prior to death, so it is also possible that those identified as veterans may have not been so. Information regarding length of time served in the military might have proven useful when considering protective factors related to service, or factors that may have led to greater trauma, but this information was unavailable due to the way veteran status was coded in the dataset. Further, it is not known whether those who identified themselves as veterans would have been considered to be so by the Veteran's Administration (who use the standards mentioned above when considering eligibility for service-related benefits). Though initial predictions regarding age of murder-suicide perpetrators were based on recent spikes in suicide in younger military members (McManus \& Wessely, 2012), it is possible that the range considered by this dataset (2003-2009) does not capture that recent increase, and the use of later samples may lessen the differences in age and their subsequent impact.

Future research on military murder-suicide should focus on application of Joiner's (2014) virtuebased typology, potentially seeking to empirically validate his work with a newer sample. Overall, important work could be completed using an updated military perpetrator sample that might include recent increases in younger perpetrators, mirroring trends in suicide research (McManus \& Wessely, 2012). Female murder-suicide perpetrators, though not examined in this study, might demonstrate different 
motives and/or precipitating factors, so other researchers might choose to explore the differences between female military and civilian murder-suicide perpetrators. Finally, later research might prioritize an investigation of prevalence of Joiner's "perverted virtues" in samples of military members experiencing significant interpersonal stressors related to murder-suicide, like depression, intimate partner conflict, physical health problems, or substance abuse. 


\section{References}

Associated Press (December 14, 2012). Killer commits suicide after massacre at school. Retrieved from http://murder-suicide.blogspot.com/2012/12/killer-commits-suicide-after-massacre.html.

Barber, C., Azrael, D., Hemenway, D. (2013, August). A truly National Violent Death Reporting System. Injury Prevention, 19(4), 225-226. doi: 10.1136/injuryprev-2013-040817.

Berman, A. L. (1979). Dyadic death: homicide-suicide. Suicide and Life-Threatening Behavior, 15-23.

Black, D. W., Carney, C. P., Peloso, P. M., Woolson, R. F., Letuchy, E., \& Doebbeling, B. N. (2005). Incarceration and veterans of the first gulf war. Military Medicine, 170, 612-618.

Blumenthal, S.J., Maliha, G., \& Mathews, A. (2012, September 14). Stopping the Surge in Military Suicides: How to Win this Preventable War. Huffington Post. Retrieved from http://www.huffingtonpost.com/susan-blumenthal/military-suicide_b_1884083.html.

Booth-Kewley, S., Larson, G. E., Highfill-McRoy, R. M., Garland, C. F., \& Gaskin, T. A. (2010). Factors associated with antisocial behavior in combat veterans. Aggressive Behavior, 36, 330-337. doi:10.1002/ab.20355.

Bossarte, R. M., Simon, T. R., \& Barker, L. (2006). Characteristics of homicide followed by suicide incidents in multiple states, 2003-2004. Injury Prevention 12, 33-38. doi:10.1136/ip.2006.012807.

Botelho, G. (2012, December 4). NFL linebacker kills baby's mother, then himself as coaches look on. Retrieved January 1, 2013, from http://edition.cnn.com/2012/12/01/sport/football/nfl-chiefsshooting/index.html.

Bryan, C. J., Jennings, K. W., Jobes, D. A., \& Bradley, J. C. (2012). Understanding military suicide. Archives of Suicide Research, 16, 95-110. doi: 10.1080/13811118.2012.667321. 
Bryan, C. J., Cukrowicz, K. C., West, C. L., \& Marrow, C. E. (2010). Combat experience and the acquired capability for suicide. Journal of Clinical Psychology, 66(10), 1044-1056. doi:10.1002/jclp.20703.

Buncombe, A. (2002). US Army stunned by spate of murders at special forces base. The Independent. Retrieved December 9, 2012, from http:/www.independent.co.uk/news/world/ americas/us-armystunned-by-spate-of-murders-at-special-forces-base-638547.html.

Bureau of Justice Statistics. (2004). Veterans in state and federal prison, 2004. Washington, D.C.: Author.

Burns, R. (2013, January 14). 2012 military suicides hit a record high of 349. Retrieved January 27, 2013, from http://bigstory.ap.org/article/2012-military-suicides-hit-record-high-349.

Byrne, C. A., \& Riggs, D. S. (1996). The cycle of trauma: Relationship aggression in male Vietnam veterans with symptoms of posttraumatic stress disorder. Violence and Victims, 11, 213-225.

Carcach, C., \& Grabosky, P. N. (1998). Murder-suicide in Australia. Australian Institute of Criminology Trends and Issues in Crime and Criminal Justice, 82.

Cavan, R. (1928). Suicide. Chicago: University of Chicago Press.

Chan, C. Y., Beh, S. L., \& Broadhurst, R. G. (2003). Homicide-suicide in Hong-Kong, 1989-1998. Forensic Science International, 137, 165-171. doi: 10.1016/S0379-0738(03)00350-5.

Elbogen, E. B., \& Johnson, S. C. (2009). The intricate link between violence and mental disorder: results from the National Epidemiologic Survey on Alcohol and Related Conditions. Archives of General Psychiatry, 66, 152-61. doi:10.1001/archgenpsychiatry.2008.537.

Felthous, A. L., \& Hempel A. (1995).Combined homicide-suicides: A review. Journal of Forensic Sciences, 40(5), 846-857. 
Flynn, S.M., Swinson, N., While, D., Hunt, I.M., Roscoe, A., Rodway, C.,... Shaw, J. (2009). Homicide followed by suicide: A cross-sectional study. The Journal of Forensic Psychiatry and Psychology, 20, 306-321. doi:10.1080/14789940802364369.

Gimbel, C., \& Booth, A. (1994). Why does military combat experience adversely affect marital relations? Journal of Marriage and Family, 56, 691-703. doi:10.2307/352879.

Gradus, J. L., Shipherd, J. C., Suvak, M. K., Giasson, H. L., \& Miller, M. (2013). Suicide attempts and suicides among Marines: A decade of follow-up. Suicide and Life-Threatening Behavior, 43 (1), 39-49. doi:10.1111/j.1943-278X.2012.00126.x.

Griffith, J. (2012). Suicide and war: The mediating effects of negative mood, post-traumatic stress disorder symptoms, and social support among Army National Guard solders. Suicide and Life-Threatening Behavior, 42(4), 453-269. doi:10.1111/j.1943-278X.2012.00104.x.

Guerra, V. S., \& Calhoun, P. S. (2011). Examining the relation between post-traumatic stress disorder and suicidal ideation in an OEF/OIF sample. Journal of Anxiety Disorders, 25, 12-18. doi:10.1016/j.janxdis.2010.06.025.

Haines, J., Williams, C. I., \& Lester, D. (2010). Murder-suicide: A reaction to interpersonal crises. Forensic Science International, 202, 93-96. doi: 10.1016/j.forsciint.2010.04.036.

Halverson, R. R., Bliese, P. D., Moore, R. E., \& Castro, C. A. (1995). Psychological well-being and physical health of soldiers deployed for Operation Uphold Democracy: A summary of human dimensions research in Haiti. Alexandria, VA: Defense Technical Information Center.

Hannah, S. G., Turf, E. E., \& Fiero, M. F. (1998). Murder-suicide in central Virginia: A descriptive epidemiologic study and empiric validation of the Hanzlick-Koponen typology. American Journal of Forensic Medicine \& Pathology, 19, 275-283. 
Hanzlick, R., \& Koponen, M. (1994). Murder-suicide in Fulton County, Georgia: Comparison with a recent report and proposed typology. American Journal for Medical Pathology, 15, 168-175.

Harper, D. W., \& Voight, L. (2007). Homicide followed by suicide: An integrated theoretical perspective. Homicide Studies, 11(4), 295-318. doi:10.1177/1088767907306993.

Joiner, T. (2014). The perversion of virtue. New York, NY: Oxford University Press.

Khadduri, J., Culhane, D.P., Cortes, A. (2010, June). Veteran Homelessness: A Supplemental Report to the 2009 Annual Homeless Assessment Report to Congress. Washington, DC: US Department of Housing and Urban Development \& Department of Veterans Affairs.

Killgore, W. D. S., Cotting, D. I., Thomas, J. L., Cox, A. L., McGurk, D., Vo, A. H., et al. (2008). Postcombat invincibility: Violent combat experiences are associated with increased risk-taking propensity following deployment. Journal of Psychiatric Research, 42, 1112-1121. doi:10.1016/j.jpsychires.2008.01.001.

Krysinka, K., \& Lester, D. (2010). Post-traumatic stress disorder and suicide risk: A systematic review. Archives of Suicide Research, 14, 1-23. doi:10.1080/13811110903478997.

Lemaire, C. M., \& Graham, D. P. (2011). Factors associated with suicidal ideation in OEF/OIF veterans. Journal of Affective Disorders, 130, 231-238. doi: 10.1016/j.jad.2010.10.021.

Lewis, C. F. (2010). Childhood antecedents of violent offending in female felons. Behavioral Sciences \& the Law, 28, 224-234. doi:10.1002/bsl.929.

Liem, M. (2010). Homicide followed by suicide: A review. Aggression and Violent Behavior, 15, 153-161. doi:10.1016/j.avb.2009.10.001.

Liem, M., Postulart, M., \& Nieuwbeerta, P. (2009). Homicide-suicide in the Netherlands: An epidemiology. Homicide Studies, 13, 99-123. doi:10.1177/1088767908330833. 
Logan, J., Hill, H. A., Lynberg Black, M., Crosby, A., Karcg, D. L., Barnes, J. D., \& Lubell, K. M. (2008). Characteristics of perpetrators in homicide-followed-by-suicide incidents: National Violent Death Reporting System - 17 U.S. States, 2003-2005. American Journal of Epidemiology, 168, 10561064.

MacManus, D., \& Wessely, S. (2012). Trauma, Psychopathology and Violence in Recent Combat Veterans. In C.S. Widom (Ed.), Trauma, Psychopathology, and Violence: Causes, Consequences, or Correlates? (pp. 267-287). New York, NY: Oxford University Press, Inc.

Malphurs, J., \& Cohen, D. (2002). A statewide case-control study of spousal homicide-suicide in older persons. American Journal of Geriatric Psychiatry, 13, 211-217. doi:10.1176/appi.ajgp.13.3.211.

Marshall, A. D., Panuzio, J., \& Taft, C. T. (2005). Intimate partner violence among military veterans and active duty servicemen. Clinical Psychology Review, 25, 862-876. doi:10.1016/j.cpr.2005.05.009.

Marzuk, P.M., Tardiff, K., \& Hirsch, C.S. (1992). The epidemiology of murder-suicide. Journal of the American Medical Association, 267(23), 3179-3183.

McCarroll, J. E., Ursano, R. J., Newby, J. H., Liu, X., Fullerton, C. S., Norwood, A. E. (2003). Domestic violence and deployment in U.S. Army soldiers. Journal of Nervous and Mental Disease, 191, 3-9.

Milliken, C. S., Auchterlonie, J. L., \& Hoge, C. W. (2007). Longitudinal assessment of mental health problems among active and reserve component returning from the Iraq war. Journal of the American Medical Association, 298, 2141-2148. doi:10.1001/jama.298.18.2141.

Moskowitz, A., Simpson, A. I. F., McKenna, B., Skipworth, J. \& Barry-Walsh, J. (2006). The role of mental illness in homicide-suicide in New Zealand, 1991-2001. Journal of Forensic Psychiatry and Psychology, 17, 417-430. doi:10.1080/14789940600761410.

Nademin, E., Jones, D. A., Pflanz, S. E., Jacoby, A. M., Ghahramanlou-Holloway, M., Campise, R.,...\& Johnson, L. (2008). An investigation of interpersonal-psychological variables in Air Force suicides: 
A controlled-comparison study. Archives of Suicide Research, 12(4), 309-325.

doi:10.1080/13811110802324847.

Napo (2009). Armed forces and the criminal justice system. Napo the Trade Union and Professional Association for Family Court and Probation Staff: London.

Nock, M. K., \& Marzuk, P. M. (1999). Murder-suicide: Phenomenology and clinical implications. In D. Jacobs (Ed). Harvard Medical School guide to suicide assessment and intervention (pp. 188-209). San Francisco: Jossey-Bass.

Nock, M. K., Deming, C. A., Fullerton, C. S., Gilman, S. E., Goldenberg, M., Kessler, R. C.,... \& Ursano, R. J. (2013). Suicide among Soldiers: A review of psychosocial risk and protective factors. Psychiatry: Interpersonal and Biological Processes, 76(2), 97-125. doi:10.1521/psyc.2013.76.2.97.

Center for Disease Control (CDC; 2013). NVDRS Timeline. Retrieved from http://www.cdc.gov/violencePrevention/NVDRS/index.html.

Orcutt, H. K., King, L. A., \& King, D. W. (2003). Male-perpetrated violence among Vietnam veteran couples: Relationships with veteran's early life characteristics, trauma history, and PTSD symptomatology. Journal of Traumatic Stress, 16, 381-290. doi:10.1023/A:1024470103325.

Prigerson, H. G., Maciejewski, P. K., \& Rosenheck, R. A. (2002). Population attributable fractions of psychiatric disorders and behavioral outcomes associated with combat exposure among U.S. men. American Journal of Public Health, 92, 59-63. doi:10.2105/AJPH.92.1.59.

Pulay, A. J., Dawson, D. A., Hasin, D. S., Goldstein, R. B., Ruan, W. J., Pickering, R. P., (2008). Violent behavior and DSM-IV psychiatric disorders: results from the national epidemiologic survey on alcohol and related conditions. Journal of Clinical Psychiatry, 69, 12-22. doi:10.4088/JCP.v69n0103. 
Scott, C. (2012, January). “Who is a Veteran?”-Basic eligibility for veterans' benefits (CRS Report No. 42324). Retrieved from Congressional Research Service website: http://www.fas.org/sgp/crs/misc/R42324.pdf.

Stack, S. (1997). Homicide followed by suicide: An analysis of Chicago data. Criminology, 35, 435-454.

Strauss, M, \& Gelles, R. (1990). How violent are American families? Estimates from the National Family Violence Resurvey and other studies. In M. A. Strauss and R. G. Gelles (Eds.), Physical violence in American families (pp. 95-112). New Brunswick, NY: Transaction.

Thomas, J. L., Wilk, J. E., Riviere, L. A., McGurk, D., Castro, C. A., \& Hoge, C. W. (2010). Prevalence of mental health problems and functional impairment among active component and National Guard soldiers 3 and 12 months following combat in Iraq. Archives of General Psychiatry, 67, 614-623. doi: 10.1001/archgenpsychiatry.2010.54.

Thompson, M., \& Gibbs, N. (2012, July). The insidious enemy: Why the Pentagon is losing the war against military suicide. Time, 180(4), 22-31.

U.S. Census Bureau. (2008). 2008 American Community Survey. Retrieved from http://www.census.gov/acs/www/data_documentation/2008_release.

Vaughan, D. (2006). Demobilised and addicted to danger. Today's Officer, Fall, 20-24.

Walsh, S., \& Hemenway, D. (2005). Intimate partner violence: homicides followed by suicides in Kentucky. Journal of the Kentucky Medical Association, 103, 10-13.

West, D. J. (1965). Murder followed by suicide. Cambridge: Harvard University Press.

Yager, T., Laufer, R., \& Gallops (1984). Some problems associated with war experience in men of the Vietnam generation. Archives of General Psychiatry, 41, 327-333. 
Yip, P. S. F., Wong, P. W. C., Cheung, Y. T., Chan, K. S., Beh, S. L. (2009). An empirical study of characteristics and types of homicide-suicides in Hong Kong, 1989-2005. Journal of Affective Disorders, 112, 184-192. doi:10.1016/j.jad.2008.05.005. 


\section{Appendix A}

$\underline{1=\text { Jealousy/Anger (Related to Romantic Dissolution) }}$ as the primary motive if:

- If the victim and the perpetrator ever had a real or perceived romantic relationship and there is clear evidence of relationship dissolution (real, pending, perceived, or historical). This dissolution includes jealousy/anger relating to romantic partner, including perceived infidelity or a lover's triangle

- Act is perpetrated against either (or both of) the real/perceived/historical romantic partner or the $\mathrm{real} / \mathrm{perceived/historical} \mathrm{romantic} \mathrm{rival} \mathrm{or} \mathrm{paramour}$

$\underline{2=\text { Benevolence }}$ as the primary motive if:

- Primary motive for murder-suicide is to end the physical suffering of a loved one (parent, child, romantic partner, etc.)

- Critical element: "but for" failing health of the victim, the murder-suicide would NOT occur. Must have evidence (notes, statements) that perpetrator committed act to end suffering.

- Suicide pact that is explicitly motivated by the alleviation of physical suffering of the victim is coded here

$\underline{3=\text { Anger/Frustration/Revenge/Spite (relating to Conflict) as the primary motive if: }}$

- Murder-suicide is the result of a conflict between individuals not directly relating to the dissolution of a romantic relationship, often involving subjects like money, housing, children, disrespect, or goal blocking. Murder-suicide completed due to feelings of anger, frustration, revenge, or spite.

- Conflicts involving romantic partners included unless evidence the argument is related to relationship dissolution. Mass and spree killings included here.

$\underline{4=\text { Depression/Psychache }}$ as the primary motive if:

- Primary motive is to alleviate the suffering of the perpetrator, who is often distraught/depressed; external stressors (job loss, financial strain, criminal charges, etc.) often present. Stressors not related to romantic or non-romantic conflict.

- If death of victims is previously agreed upon (i.e., a suicide pact), death of victims is not a primarily result of the victim's illness or suffering.

$\underline{\mathbf{5}=\text { Delusional/Psychosis/Mental Illness }}$ as the primary motive if:

- Explicit evidence of psychosis, hallucinations, or other extreme misperception/delusions. Present at time of incident or very close proximity to incident and is primary cause. May be drug-induced.

$\underline{6=U n k n o w n}$ as the primary motive if:

- Motive is unknown - cannot be reliably surmised from given information 


\section{Appendix B}

Table B1

Demographic characteristics of all murder-suicide perpetrators.

\begin{tabular}{|l|l|}
\hline Characteristics & $\begin{array}{l}\text { Total, } \mathbf{n = 5 1 8} \\
(\mathbf{1 0 0} \%)\end{array}$ \\
\hline Age (years) & $37(7.1 \%)$ \\
$17-24$ & $80(15.4 \%)$ \\
$25-34$ & $118(22 \%)$ \\
$35-44$ & $109(21 \%)$ \\
$45-54$ & $71(13.7 \%)$ \\
$55-64$ & $107(20.7 \%)$ \\
65+ & \\
\hline Race & $397(76.6 \%)$ \\
White & $100(19.3 \%)$ \\
Black & $6(1.2 \%)$ \\
American Indian & $13(2.5 \%)$ \\
Asian/Pacific Islander & $2(0.4 \%)$ \\
Unknown & \\
\hline Ethnicity & $478(92.3 \%)$ \\
Non-Hispanic & $35(6.8 \%)$ \\
Hispanic & $5(1 \%)$ \\
Unknown & \\
\hline Marital status & $172(33.2 \%)$ \\
Married & $99(19.1 \%)$ \\
Never married & $147(28.4 \%)$ \\
Widowed & $85(16.4 \%)$ \\
Divorced & $4(0.8 \%)$ \\
Married but separated & $4(0.8 \%)$ \\
Single, not otherwise specified & $7(1.4 \%)$ \\
Unknown & \\
Education (Highest completed) & $40(7.7 \%)$ \\
Some high school, no diploma & $103(19.9 \%)$ \\
High school/GED & $30(6.2 \%)$ \\
Some college, no degree & $10(5.8 \%)$ \\
Associate's degree & $7(1.9 \%)$ \\
Bachelor's degree & $0(0 \%)$ \\
Professional/advanced & $303(58.5 \%)$ \\
Unknown & \\
\hline
\end{tabular}


Table B2

Victim relationship to perpetrator and primary motive for all murder-suicide perpetrators.

\begin{tabular}{|l|l|}
\hline Characteristics & $\begin{array}{l}\text { Total, } \mathbf{n}=\mathbf{5 1 8} \\
\mathbf{( 1 0 0 \% )}\end{array}$ \\
\hline Victim relationship to perpetrator & \\
Spouse/intimate partner & $393(75.9 \%)$ \\
Parent & $14(2.7 \%)$ \\
Child & $23(4.4 \%)$ \\
Other relative & $7(1.4 \%)$ \\
Additional intimate partner (i.e., wife's boyfriend) & $20(3.9 \%)$ \\
Acquaintance/friend & $37(7.1 \%)$ \\
Stranger & $3(0.6 \%)$ \\
Law enforcement officer & $3(0.6 \%)$ \\
Unknown & $18(3.5 \%)$ \\
\hline Primary motive & $190(36.7 \%)$ \\
Jealousy/anger (relationship dissolution) & $25(4.8 \%)$ \\
Benevolence & $128(24.7 \%)$ \\
Anger/frustration/revenge/spite (conflict) & $79(15.3 \%)$ \\
Depression/psychache & $5(1 \%)$ \\
Delusional/psychosis/mental illness & $91(17.6 \%)$ \\
Unknown &
\end{tabular}


Table B3

Behavioral health characteristics of all murder-suicide perpetrators.

\begin{tabular}{|l|l|}
\hline Characteristics & $\begin{array}{l}\text { Total, } \mathbf{n = 5 1 8} \\
(\mathbf{1 0 0 \%})\end{array}$ \\
\hline Behavioral health characteristics & \\
$\quad$ History of suicide attempts & $16(3.1 \%)$ \\
History of mental health treatment & $46(8.9 \%)$ \\
Physical health problems & $43(8.3 \%)$ \\
Current depressed mood & $64(12.4 \%)$ \\
Current substance abuse & $36(6.9 \%)$ \\
Current alcohol dependence & $38(7.3 \%)$ \\
Current use of antidepressants & $25(4.8 \%)$ \\
Current mental health problem & $58(11.2 \%)$ \\
Suspected intoxication & $116(22.4 \%)$ \\
Disclosed suicidal intent & $58(11.2 \%)$ \\
Left suicide note & $116(22.4 \%)$ \\
\hline
\end{tabular}


Table B4

Event-contextual characteristics of all murder-suicides.

\begin{tabular}{|l|l|}
\hline Characteristics & $\begin{array}{l}\text { Total, } \mathbf{n = 5 1 8} \\
\mathbf{( 1 0 0 \% )}\end{array}$ \\
\hline Location & $311(60 \%)$ \\
Apartment/home & $196(37.8 \%)$ \\
Outside of home & $11(2.1 \%)$ \\
Unknown & \\
\hline Primary weapon used & $456(88 \%)$ \\
Firearm & $17(3.3 \%)$ \\
Hanging/strangling/suffocation & $16(3.1 \%)$ \\
Sharp instrument & $1(0.2 \%)$ \\
Blunt instrument & $11(2.1 \%)$ \\
Poison & $2(0.4 \%)$ \\
Falls & $1(0.2 \%)$ \\
Explosive & $3(0.6 \%)$ \\
Drowning & $5(1 \%)$ \\
Fire or burns & $3(0.6 \%)$ \\
Motor vehicle & $1(0.2 \%)$ \\
Other & \\
Life-event factors + & $379(73.2 \%)$ \\
Intimate partner problem & $58(11.2 \%)$ \\
Other relationship problems & $97(18.7 \%)$ \\
Recent criminal legal problem & $26(5 \%)$ \\
Other legal problem & $45(6.8 \%)$ \\
Job problems & $24(8.7 \%)$ \\
Financial problems & \\
&
\end{tabular}

Note. More than one stressor may have been endorsed in each case. 
Table 1

Comparison of demographic characteristics of military versus civilian murder-suicide perpetrators.

\begin{tabular}{|c|c|c|c|}
\hline Characteristics & $\begin{array}{l}\text { Military perpetrators, } \\
\mathrm{n}=\mathbf{2 5 9}(50 \%)\end{array}$ & $\begin{array}{l}\text { Civilian perpetrators, } \\
\mathrm{n}=259(50 \%)\end{array}$ & P-value \\
\hline Age aggregate (years) & & & $<0.001$ \\
\hline $17-24$ & $7(2.7 \%)$ & $30(11.6 \%)$ & \\
\hline $25-34$ & $21(8.1 \%)$ & $59(22.8 \%)$ & \\
\hline $35-44$ & $41(15.8 \%)$ & $73(28.2 \%)$ & \\
\hline $45-54$ & $56(21.6 \%)$ & $53(20.5 \%)$ & \\
\hline $55-64$ & $45(17.4 \%)$ & $26(10 \%)$ & \\
\hline $65+$ & $89(34.4 \%)$ & $18(6.9 \%)$ & \\
\hline Mean age (SD) & $57.05(18.06)$ & $41.56(13.72)$ & $<0.001$ \\
\hline Race & & & $<0.001$ \\
\hline White & $208(80.3 \%)$ & $189(73 \%)$ & \\
\hline Black & $50(19.3 \%)$ & $50(19.3 \%)$ & \\
\hline American Indian & $0(0 \%)$ & $6(2.3 \%)$ & \\
\hline Asian/Pacific Islander & $1(0.4 \%)$ & $12(4.6 \%)$ & \\
\hline Unknown & $0(0 \%)$ & $2(0.8 \%)$ & \\
\hline Ethnicity & & & 0.227 \\
\hline Non-Hispanic & $244(94.2 \%)$ & $234(90.3 \%)$ & \\
\hline Hispanic & $13(5 \%)$ & $22(8.5 \%)$ & \\
\hline Unknown & $2(0.8 \%)$ & $3(1.2 \%)$ & \\
\hline Marital status & & & $<0.001$ \\
\hline Married & $100(38.6 \%)$ & $72(27.8 \%)$ & \\
\hline Never married & $30(11.6 \%)$ & $69(26.6 \%)$ & \\
\hline Widowed & $81(31.3 \%)$ & $66(25.5 \%)$ & \\
\hline Divorced & $44(17 \%)$ & $41(15.8 \%)$ & \\
\hline Married but separated & $0(0 \%)$ & $4(1.5 \%)$ & \\
\hline Single, not otherwise specified & $1(0.4 \%)$ & $3(1.2 \%)$ & \\
\hline Unknown & $3(1.2 \%)$ & $4(1.5 \%)$ & \\
\hline Education (Highest completed) & & & 0.005 \\
\hline Some high school, no diploma & $8(3.1 \%)$ & $32(12.4 \%)$ & \\
\hline High school/GED & $56(21.6 \%)$ & $47(18.1 \%)$ & \\
\hline Some college, no degree & $16(6.2 \%)$ & $16(6.2 \%)$ & \\
\hline Associate's degree & $15(5.8 \%)$ & $15(5.8 \%)$ & \\
\hline Bachelor's degree & $4(1.5 \%)$ & $6(2.3 \%)$ & \\
\hline Professional/advanced & $0(0 \%)$ & $0(0 \%)$ & \\
\hline Unknown & $160(61.8 \%)$ & $143(55.2 \%)$ & \\
\hline
\end{tabular}

Note. Variables in bold were identified by cross-tabulation to be significantly different from one another. Mean age of murder-suicide perpetrators was compared using an independent $t$-test. 
Table 2. Victim relationship to perpetrator and primary motive.

\begin{tabular}{|c|c|c|c|}
\hline Characteristics & $\begin{array}{l}\text { Military } \\
\text { perpetrators, } \\
\mathbf{n}=\mathbf{2 5 9}(\mathbf{5 0 \%})\end{array}$ & $\begin{array}{l}\text { Civilian } \\
\text { perpetrators, } \\
n=259(50 \%)\end{array}$ & P-value \\
\hline $\begin{array}{l}\text { Victim relationship to perpetrator } \\
\text { Spouse/intimate partner } \\
\text { Parent } \\
\text { Child } \\
\text { Other relative } \\
\text { Additional intimate partner (i.e., wife's boyfriend) } \\
\text { Acquaintance/friend } \\
\text { Stranger } \\
\text { Law enforcement officer } \\
\text { Unknown }\end{array}$ & $\begin{array}{l}203(78.4 \%) \\
6(2.3 \%) \\
13(5 \%) \\
2(0.8 \%) \\
7(2.7 \%) \\
18(6.9 \%) \\
3(1.2) \\
2(0.8 \%) \\
5(1.9 \%)\end{array}$ & $\begin{array}{l}190(73.4 \%) \\
8(3.1 \%) \\
10(3.9 \%) \\
5(1.9 \%) \\
13(5 \%) \\
19(7.3 \%) \\
0(0 \%) \\
1(0.4 \%) \\
13(5 \%)\end{array}$ & 0.200 \\
\hline $\begin{array}{l}\text { Primary motive } \\
\text { Jealousy/anger (relationship dissolution) } \\
\text { Benevolence } \\
\text { Anger/frustration/revenge/spite (conflict) } \\
\text { Depression/psychache } \\
\text { Delusional/psychosis/mental illness } \\
\text { Unknown }\end{array}$ & $\begin{array}{l}75(\mathbf{2 9} \%) \\
17(6.6 \%) \\
56(21.6 \%) \\
\mathbf{5 4}(\mathbf{2 0 . 8 \% )} \\
4(1.5 \%) \\
53(20.5 \%)\end{array}$ & $\begin{array}{l}\mathbf{1 1 5}(\mathbf{4 4 . 4 \% )}) \\
8(3.1 \%) \\
72(27.8 \%) \\
\mathbf{2 5}(\mathbf{9 . 7 \% )} \\
1(0.4 \%) \\
38(14.7 \%)\end{array}$ & $<0.001$ \\
\hline
\end{tabular}

Note. Variables in bold were identified by cross-tabulation to be significantly different from one another. 
Table 3

Behavioral health characteristics of military versus civilian murder-suicide perpetrators.

\begin{tabular}{llll}
\hline Characteristics & $\begin{array}{l}\text { Military } \\
\text { perpetrators, } \\
\mathbf{n = 2 5 9}(\mathbf{5 0 \% )}\end{array}$ & $\begin{array}{l}\text { Civilian } \\
\text { perpetrators, } \\
\mathbf{n = 2 5 9}(\mathbf{5 0} \%)\end{array}$ & P-value \\
\hline Behavioral health characteristics & & & \\
$\quad$ History of suicide attempts & $9(3.5 \%)$ & $7(2.7 \%)$ & 0.801 \\
History of mental health treatment & $24(9.3 \%)$ & $22(8.5 \%)$ & 0.877 \\
Physical health problems & $\mathbf{3 7}(\mathbf{1 4 . 3 \% )}$ & $\mathbf{6}(\mathbf{2 . 3 \% )}$ & $<\mathbf{0 . 0 0 1}$ \\
Current depressed mood & $32(12.4 \%)$ & $32(12.4 \%)$ & 1.000 \\
Current substance abuse & $12(4.6 \%)$ & $24(9.3 \%)$ & 0.056 \\
Current alcohol dependence & $19(7.3 \%)$ & $19(7.3 \%)$ & 1.000 \\
Current use of antidepressants & $11(4.2 \%)$ & $14(5.4 \%)$ & 0.875 \\
Current mental health problem & $31(12 \%)$ & $27(10.4 \%)$ & 0.676 \\
Suspected intoxication & $\mathbf{4 6}(\mathbf{1 7 . 8 \% )}$ & $\mathbf{7 0}(\mathbf{2 7 \%})$ & $\mathbf{0 . 0 2 0}$ \\
Disclosed suicidal intent & $29(11.2 \%)$ & $29(18.9 \%)$ & 0.555 \\
Left suicide note & $67(25.9 \%)$ & $49(18.9 \%)$ & 0.073 \\
\hline
\end{tabular}

Note. Variables in bold were identified by cross-tabulation to be significantly different from one another. 
Table 4

Event-contextual characteristics of military versus civilian murder-suicides

\begin{tabular}{|c|c|c|c|}
\hline Characteristics & $\begin{array}{l}\text { Military murder- } \\
\text { suicide, } \\
\mathbf{n}=\mathbf{2 5 9}(\mathbf{5 0 \%})\end{array}$ & $\begin{array}{l}\text { Civilian murder- } \\
\text { suicide, } \\
\mathrm{n}=259(\mathbf{5 0} \%)\end{array}$ & P-value \\
\hline Location & & & 0.004 \\
\hline Apartment/home & $172(66.4 \%)$ & $139(53.7 \%)$ & \\
\hline Outside of home & $80(30.9 \%)$ & $116(44.8 \%)$ & \\
\hline Unknown & $7(2.7 \%)$ & $4(1.5 \%)$ & \\
\hline Primary weapon used & & & 0.148 \\
\hline Firearm & $226(87.3 \%)$ & $230(88.8 \%)$ & \\
\hline Hanging/strangling/suffocation & $6(2.3 \%)$ & $11(4.2 \%)$ & \\
\hline Sharp instrument & $11(4.2 \%)$ & $5(1.9 \%)$ & \\
\hline Blunt instrument & $1(0.4 \%)$ & $0(0 \%)$ & \\
\hline Poison & $4(1.5 \%)$ & $7(2.7 \%)$ & \\
\hline Falls & $2(0.8 \%)$ & $0(0 \%)$ & \\
\hline Explosive & $1(0.4 \%)$ & $0(0 \%)$ & \\
\hline Drowning & $3(1.2 \%)$ & $0(0 \%)$ & \\
\hline Fire or burns & $2(0.8 \%)$ & $3(1.2 \%)$ & \\
\hline Motor vehicle & $1(0.2 \%)$ & $2(0.4 \%)$ & \\
\hline Other & $0(0 \%)$ & $1(0.4 \%)$ & \\
\hline \multicolumn{4}{|l|}{ Life-event factors } \\
\hline Intimate partner problem & $178(68.7 \%)$ & $201(77.6 \%)$ & 0.029 \\
\hline Other relationship problems & $23(12.7 \%)$ & $35(9.7 \%)$ & 0.329 \\
\hline Recent criminal legal problem & $43(16.6 \%)$ & $54(20.8 \%)$ & 0.260 \\
\hline Other legal problem & $12(4.6 \%)$ & $14(5.4 \%)$ & 0.841 \\
\hline Job problems & $28(7.3 \%)$ & $17(6.2 \%)$ & 0.727 \\
\hline Financial problems & $16(10.8 \%)$ & $8(6.6 \%)$ & 0.118 \\
\hline
\end{tabular}

Note. Variables in bold were identified by cross-tabulation to be significantly different from one another. More than one type of stressor may have been endorsed in each case. 
Table 5

Logistic regression for military versus civilian perpetrators with age included as a predictor

\begin{tabular}{|c|c|c|c|c|c|c|}
\hline Variable & B & $\mathrm{SE}$ & $\begin{array}{l}\text { Wald } \\
\text { statistic }\end{array}$ & df & $\mathrm{P}$ & $\begin{array}{l}\text { Odds } \\
\text { Ratio }\end{array}$ \\
\hline \multicolumn{7}{|l|}{ Demographic factors } \\
\hline Age & .053 & .009 & 33.82 & 1 & .000 & 1.05 \\
\hline White ethnicity & 166 & .283 & .343 & 1 & .558 & .847 \\
\hline Never married & .244 & .321 & .578 & 1 & .447 & .784 \\
\hline \multicolumn{7}{|l|}{ Motive } \\
\hline Benevolence & -.637 & .584 & 1.19 & 1 & .275 & .529 \\
\hline Conflict & .084 & .271 & .096 & 1 & .757 & 1.09 \\
\hline Depression/psychache & .100 & .367 & .074 & 1 & .785 & 1.11 \\
\hline \multicolumn{7}{|l|}{ Behavioral health } \\
\hline Physical health problems & .964 & .530 & 3.31 & 1 & .069 & 2.62 \\
\hline Substance abuse & -.515 & .449 & 1.32 & 1 & .251 & .597 \\
\hline Suspected intoxication & -.074 & .269 & .075 & 1 & .784 & .929 \\
\hline Left suicide note & -.221 & .290 & .582 & 1 & .446 & .802 \\
\hline \multicolumn{7}{|l|}{ Event-contextual factors } \\
\hline At person's home & .183 & .234 & .610 & 1 & .435 & 1.20 \\
\hline Intimate partner problem & -.372 & .295 & 1.59 & 1 & .208 & .690 \\
\hline \multicolumn{7}{|l|}{ Overall model evaluation } \\
\hline Likelihood ratio test & & & 95.36 & 12 & $<.001$ & \\
\hline \multicolumn{7}{|l|}{ Goodness-of-fit test } \\
\hline Hosmer and Lemeshow & & & 4.135 & 8 & .845 & \\
\hline
\end{tabular}

Note. $0=$ civilians, $1=$ military. Cox and Snell $\mathrm{R}^{2}=.214$, Nagelkerke $\mathrm{R}^{2}=.285$. Variables in bold identified as significant. Jealousy/anger related to relationship dissolution was used as the comparison group for the step containing motives. The odds ratio is used to describe the relative odds of membership to the military perpetrator group, given exposure to the variable of interest. Values of greater than one indicate that members of the military perpetrator group are more likely than civilian perpetrators to be exposed to that variable. Non-significant values for the Hosmer and Lemeshow test are desired and suggests the model fits the data well. 
Table 6

Logistic regression for military versus civilian perpetrators including only secondary predictors (age excluded)

\begin{tabular}{|c|c|c|c|c|c|c|}
\hline Variable & B & SE & $\begin{array}{l}\text { Wald } \\
\text { statistic }\end{array}$ & $\mathrm{df}$ & $\mathrm{P}$ & $\begin{array}{l}\text { Odds } \\
\text { Ratio }\end{array}$ \\
\hline \multicolumn{7}{|l|}{ Demographic factors } \\
\hline Never married & -.822 & .277 & 8.80 & 1 & .003 & .439 \\
\hline \multicolumn{7}{|l|}{ Motive } \\
\hline Depression/psychache & .600 & .294 & 4.16 & 1 & .041 & 1.82 \\
\hline \multicolumn{7}{|l|}{ Behavioral health } \\
\hline Physical health problems & -1.610 & .474 & 11.54 & 1 & .001 & 5.03 \\
\hline Substance abuse & .798 & .433 & 3.40 & 1 & .065 & .450 \\
\hline \multicolumn{7}{|l|}{ Overall model evaluation } \\
\hline Likelihood ratio test & & & 47.70 & 4 & $<.001$ & \\
\hline \multicolumn{7}{|l|}{ Goodness-of-fit test } \\
\hline Hosmer and Lemeshow & & & 1.66 & 4 & .798 & \\
\hline
\end{tabular}

Note. $0=$ civilians, $1=$ military. Cox and Snell $\mathrm{R}^{2}=.214$, Nagelkerke $\mathrm{R}^{2}=.285$. Variables in bold identified as significant. The odds ratio is used to describe the relative odds of membership to the military perpetrator group, given exposure to the variable of interest. Values of greater than one indicate that members of the military perpetrator group are more likely than civilian perpetrators to be exposed to that variable. Non-significant values for the Hosmer and Lemeshow test is desired and suggests the model fits the data well. 
Table 7

Correlations between demographic factors, motives, behavioral health variables, and event-contextual factors identified as significant in univariate analyses

\begin{tabular}{|c|c|c|c|c|c|c|c|c|}
\hline Variable & 1. & 2. & 3. & 4. & 5. & 6. & 7. & 8. \\
\hline 1. Age (years) & --- & & & & & & & \\
\hline 2. White ethnicity & $.29 * *$ & --- & & & & & & \\
\hline 3. Never married & $-.42 * *$ & $-.18 * *$ & --- & & & & & \\
\hline 4. Jealousy/anger & $-.28 * *$ & $-.12 *$ & -.01 & --- & & & & \\
\hline 5. Depression/psychache & $.38 * *$ & $.19 * *$ & $-.16 * *$ & $-.44 * *$ & --- & & & \\
\hline 6. Physical health problems & $.43 * *$ & $.16^{* *}$ & $-.15 * *$ & $-.27 * *$ & $.39 * *$ & --- & & \\
\hline 7. Suspected intoxication & $-.18 * *$ & .03 & .02 & -.01 & $-.11 *$ & -.10 & --- & \\
\hline 8. At person's home & $.29 * *$ & $.11^{*}$ & $-.16 * *$ & $-.22 * *$ & $.19 * *$ & $.25 * *$ & .00 & --- \\
\hline 9. Intimate partner problem & $-.21 * *$ & $-.20 * *$ & $-.10 *$ & $.37 * *$ & $-.19 * *$ & $-.21 * *$ & $.13 * *$ & $-.11 *$ \\
\hline
\end{tabular}

**Correlation is significant at the .01 level.

*Correlation is significant at the .05 level. 
Table 8

Comparison of mean age of murder-suicide and suicide-only perpetrators.

\begin{tabular}{lcccc}
\hline & \multicolumn{2}{c}{ Murder-suicide } & \multicolumn{2}{c}{ Suicide only } \\
\cline { 2 - 5 } & $\mathrm{M}(\mathrm{SD})$ & $\mathrm{n}$ & $\mathrm{M}(\mathrm{SD})$ & $\mathrm{n}$ \\
\hline Military perpetrators & $\mathbf{5 7 . 0 4 ( 1 7 . 6 3 )}$ & $\mathbf{2 5 9}$ & $\mathbf{5 7 . 0 9}(\mathbf{1 7 . 1 6 )}$ & $\mathbf{2 5 9}$ \\
Civilian perpetrators & $\mathbf{4 1 . 6 3 ( 1 4 . 1 5 )}$ & $\mathbf{2 5 9}$ & $\mathbf{4 3 . 4 5 ( 1 5 . 9 4 )}$ & $\mathbf{2 5 9}$ \\
\hline
\end{tabular}

Note. Variables in bold were identified as significantly different from one another in an independent $t$-test, $\mathrm{p}<.001$. 


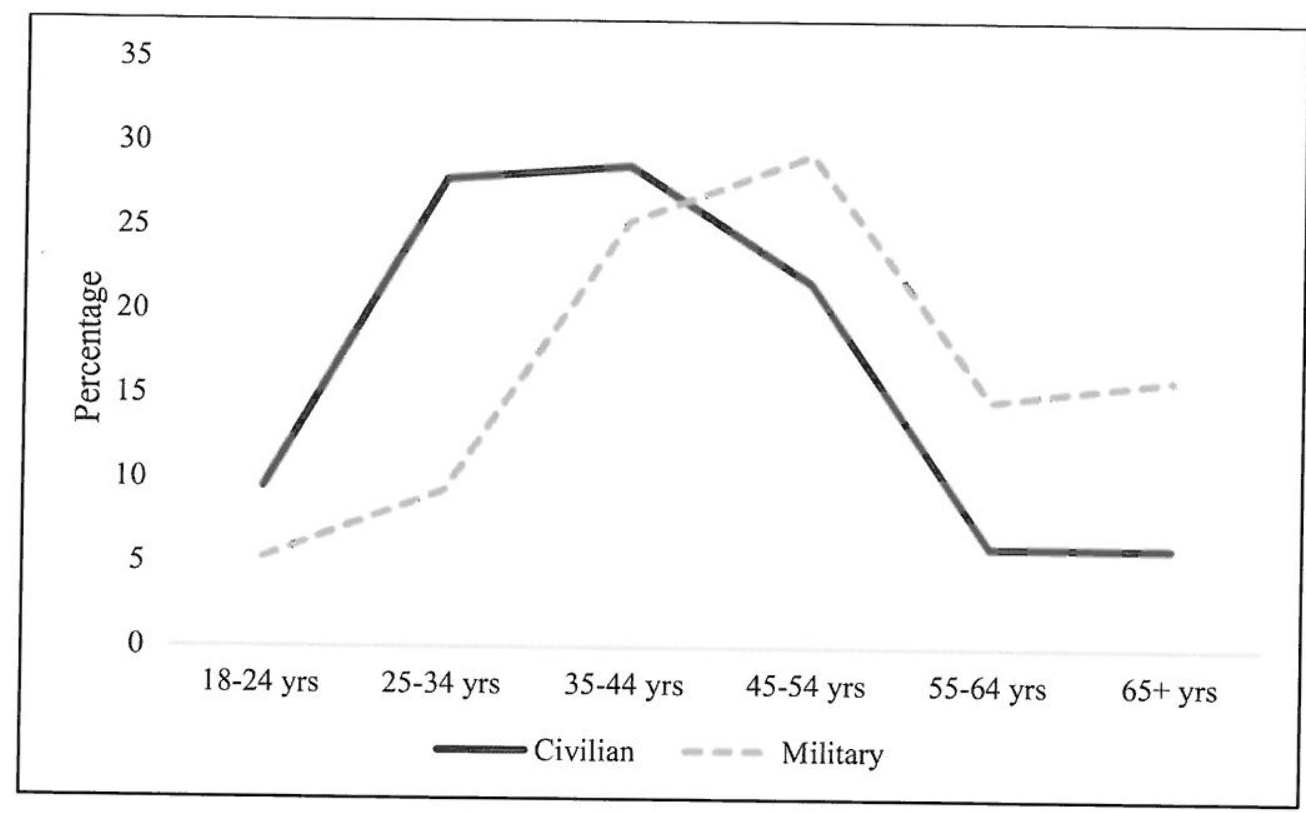

Figure 1. Percentage of all cases of murder-suicide with jealousy/anger related to relationship dissolution motive calculated for each age aggregate. 


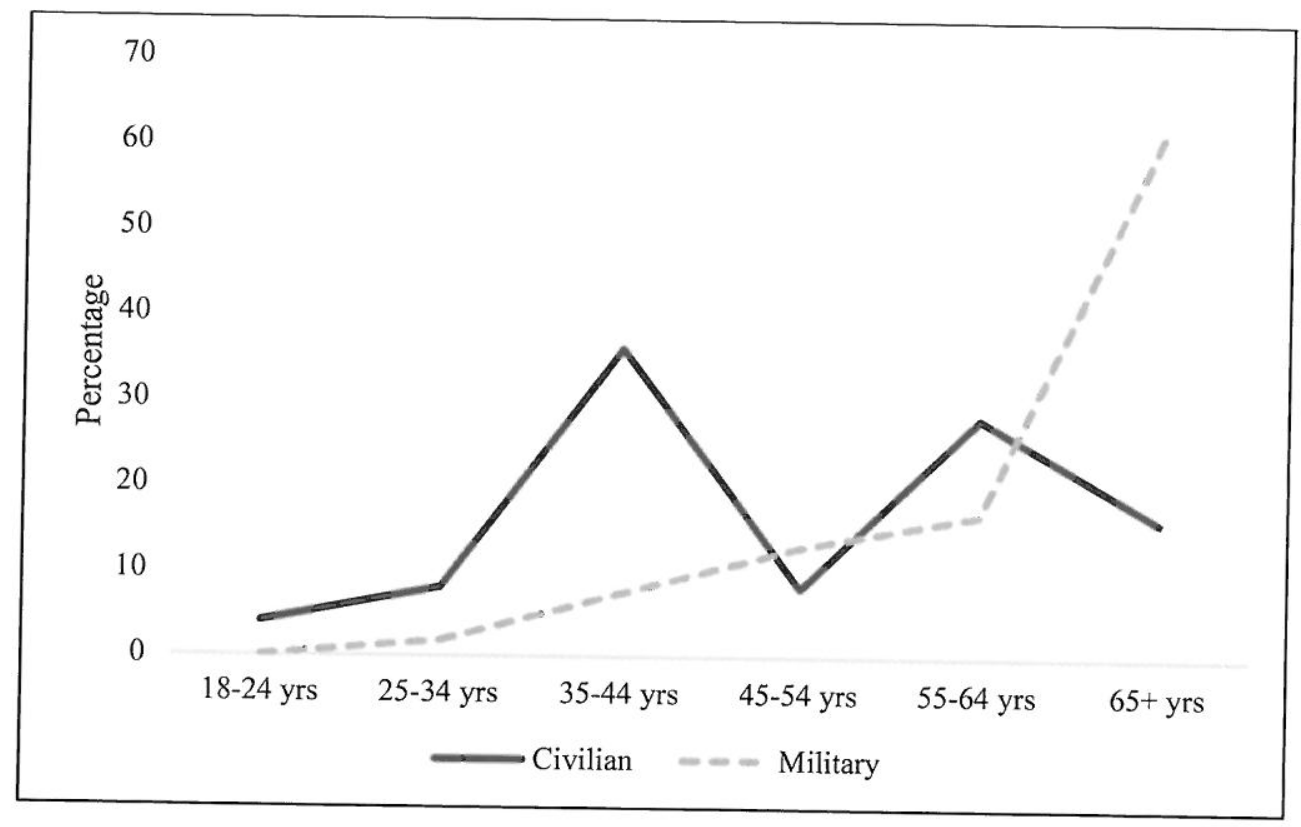

Figure 2. Percentage of all murder-suicides with the depression/psychache motive calculated for each age aggregate. 